\title{
Article \\ The Place of Energy Security in the National Security Framework: An Assessment Approach
}

\author{
Daniel Mara ${ }^{1}$, Silviu Nate ${ }^{2, * \mathbb{C}}$, Andriy Stavytskyy ${ }^{3}$ and Ganna Kharlamova ${ }^{3}$ a(d) \\ 1 Faculty of Social Sciences and Humanities, Lucian Blaga University of Sibiu, 550024 Sibiu, Romania; \\ daniel.mara@ulbsibiu.ro \\ 2 Department of International Relations, Political Science and Security Studies, \\ Lucian Blaga University of Sibiu, 550324 Sibiu, Romania \\ 3 Department of Economic Cybernetics, Taras Shevchenko National University of Kyiv, 01601 Kyiv, Ukraine; \\ a.stavytskyy@gmail.com (A.S.); akharlamova@ukr.net (G.K.) \\ * Correspondence: silviu.nate@ulbsibiu.ro; Tel.: +40-744-768-840
}

check for updates

Citation: Mara, D.; Nate, S.; Stavytskyy, A.; Kharlamova, G. The Place of Energy Security in the National Security Framework: An Assessment Approach. Energies 2022, 15, 658. https://doi.org/10.3390/ en15020658

Academic Editor: JongRoul Woo

Received: 1 December 2021

Accepted: 14 January 2022

Published: 17 January 2022

Publisher's Note: MDPI stays neutral with regard to jurisdictional claims in published maps and institutional affiliations.

Copyright: (C) 2022 by the authors. Licensee MDPI, Basel, Switzerland. This article is an open access article distributed under the terms and conditions of the Creative Commons Attribution (CC BY) license (https:// creativecommons.org/licenses/by/ $4.0 /)$.

\begin{abstract}
The term "energy security" is used almost everywhere in economic and political discussions related to energy supply. However, different authors use different meanings to express the concept of energy security. Quite often, this term is used to give more importance or relevance to issues that are often not inherently related to energy security. Attempts to define the essence of the concept of "energy security" have hitherto not been systematic and are characterized by a variety of approaches, and some insufficient justification especially in the aspect of state national security is notable. Our contribution to the discourse development is the consideration of energy security as part of internationally recognized indices that are developed to assess the temperature of world security. A regression modeling approach to test the crucial factors of social-economic development that impact the energy security indicators is presented. The literature analysis and review of the world's existing national security indices show that the link between energy security and national security is in fact hardly considered. Mostly, energy security is considered in the dichotomy concerning economic security at the international, as well as national levels. The calculative regression modeling revealed that the significant correlation of economic and energy security is just for the U.S.A., the rest of the analyzed countires display the weak or non-significant correlations of the indices of economic/energy/security threats. That pushes the discussion on whether energy security is indeed so impactful a factor for geo-policy and geo-economy, or whether it is mostly the well-rolled media-supported megatrend. However, the present study notes a great shortage of long-term cross-state indices to reflect energy, economic, and national security to allow for valuable modeling.
\end{abstract}

Keywords: regression; economic security; energy; Ukraine; correlations; China; U.S.A.

\section{Introduction}

The issue of energy security has come to the fore, in discussions at multilateral global and international regional forums. Energy is a key economic sector for many countries in economic, social, and political terms [1]. At the end of the twentieth century, cooperation in the energy sector intensified markedly, especially after the crises (2008 year, particularly) that caused serious shocks in the world economy. The desire to solve these problems has led to a significant intensification of international energy policy on a global and regional scale. The internationalization and globalization of energy as an industry, as well as the strengthening of energy interdependence of most countries, increasingly confirms the thesis of the inability to ensure national energy security [2], which led to an understanding of the need for international energy security at regional and global levels [3].

Energy security is largely determined by the state of global energy markets, which are becoming increasingly global. Currently, there is the development of a competitive 
environment in these markets, which further leads to the intensification of international companies and intensification of the struggle between them [4].

For some countries (i.e., Ukraine), energy security is the main condition for its existence as an independent state, primarily due to the energy consumption of the economy and inefficient use of energy resources, a reduction of the internal resource base of the fuel, and a fragile energy complex [5].

The example of Ukraine aptly demonstrates how energy security is extremely important and requires increased attention from the state and the public, if the country wants to remain an independent and sovereign country. The issue is that the state is deprived of access to certain areas of the sea shelf, where the start of industrial energy production was carried out or planned. There is a partial destruction of the energy complex of Ukraine, including the physical destruction of some energy and heat generation facilities, of the coal industry, as well as energy infrastructure in the Donetsk and Luhansk regions, as well as the illegal alienation of energy facilities in the Crimea peninsula [6].

The energy crisis can threaten not only an individual country or continent, but all of humanity. The world community is most concerned about the limited reserves of natural gas and oil, so the inefficient use of fuel and energy resources and high levels of $\mathrm{CO}_{2}$ emissions threaten the future of all mankind. The issue of energy security is relevant for all countries of the world, regardless of their energy resources. At the same time, the degree of resource provision affects the number of tasks for energy security and their importance. So, nowadays, one of the important components of a country's national security is energy security, regardless of whether it is considered in the context of a country exporting or importing energy resources.

An important component of further analysis is to determine the place of the energy component in ensuring national security. On the one hand, the role of fossil fuel-based energy resources is decreasing, the world is gradually moving to the use of alternative fuel sources [7]. On the other hand, there is an active struggle in the world, and sometimes a war for various energy resources. For this reason, the present work aims to determine the role of the energy component in ensuring national security and to identify certain factors that determine the behavior of countries in the energy sector in the modern world.

Thus, the main goal of the work is to determine how the national and energy security of countries are interconnected, and whether energy resources can play a more important role in geopolitical actions in the world. The answer to this question will allow for a clearer prediction of the behavior of countries around the world, the role of countries exporting energy resources in ensuring world order.

Structurally, the work consists of certain blocks. First, the issue of the exact understanding of energy security is presented, as well as what its manifestations are in different countries of the world. Countries that are quite diverse are selected for the analysis: the United States; as one of the superpowers; China, as a country that ranks second in strength, but differs significantly in the structure of the economy from the United States; Norway, a state that has almost completely switched to alternative energy sources for domestic consumption; and Ukraine, a country that has lost almost a quarter of its industrial and energy potential as a result of the temporary occupation of its territory. The next step is to study the geopolitical aspects of energy security in different parts of the world, in particular, the identification of current conflicts, which is the basis for the struggle for energy and other resources. The following sections present the research methodology and the obtained results. Then, the conclusions and discussion are determined by using the results received. In addition to a critical review of the existing literature and the practical state strategies on the duality of national security and energy security, the analysis of contemporary global indices is presented to depict the level of the emphasis on energy security.

\section{Literature Review}

Energy security: national dimensions. Scientists and policymakers all over the world do not argue that energy security can be defined as a state of the economy that guarantees the 
technically and economically safe satisfaction of the current and future needs of consumers concerning energy and the protection of the environment [8]. Each state tries to implement its interconnected set as effectively as possible. Independent energy policy is a central issue that is used to ensure the national interests of the state. The factors influencing energy independence are the following: opportunities for the personal production of coal, oil, and gas; renewable energy generation; nuclear energy generation; the generation of electricity from other energy resources; and the level of diversification of imports of these energy resources [9]. However, the in-depth analyses of particular countries could reveal some concerns and paradoxes.

China case. The Chinese understand energy security as "a state in which sufficient and reliable supplies of energy resources are guaranteed at affordable prices, and supply agreements do not jeopardize the nation's core values and do not interfere with the achievement of other goals." [10] China's energy security is becoming more important against the background of sharp fluctuations in world oil prices. Therefore, the main strategic task of Chinese leadership is to find reasonable options for solving problems in the field of energy security. Global reserves of oil and other hydrocarbon fuels are constantly declining, forcing the use of alternative energy sources, environmentally friendly technologies, and renewable energy sources (e.g., hydropower, biogas, and nuclear energy). All these factors contribute to the development of a modern and comprehensive concept of Chinese energy security [11].

The development of the energy complex in China is taking place with certain features. The main one is the constant growth of the demand for basic energy sources. According to China's National Bureau of Statistics [12], China's annual growth in energy consumption (Figure 1) will be at least $7.5 \%$ over the next two decades, while the current positive dynamics of economic development and economic growth will continue. China heavily invests in the development and implementation of technologies for processing coal into liquid fuel. Natural gas is no longer considered a leading fuel for China by most analysts (Figure 2) [13].

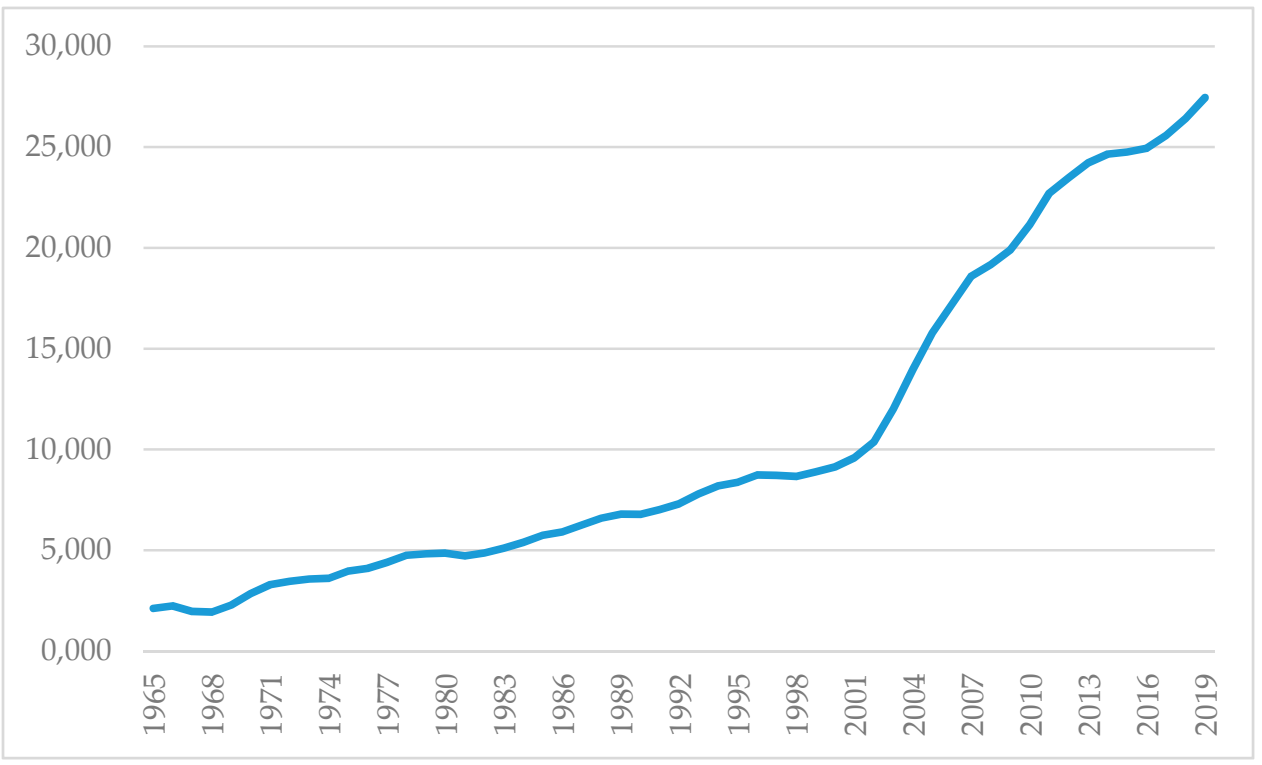

Figure 1. Energy consumption per capita (kWh) in China (according to the data source [14]). 


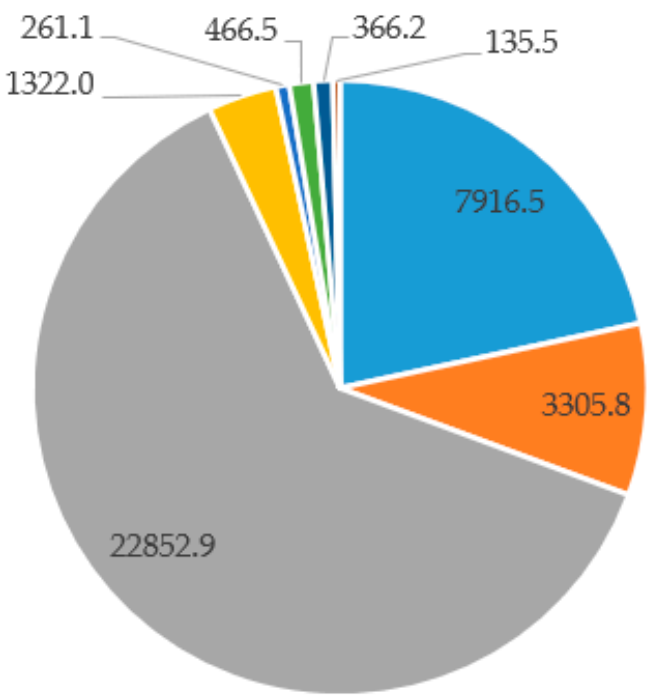

- Oil Consumption - TWh

- Gas Consumption - TWh

- Coal Consumption - TWh

- Hydro Generation - TWh

- Solar Generation - TWh

- Wind Generation - TWh

- Nuclear Generation - TWh

- Geo Biomass Other - TWh

Figure 2. The energy consumption resource distribution in China in 2020 (according to the data source [14]).

China is striving for revolutionary changes in energy consumption, namely the cessation of unjustified energy consumption, the introduction of energy efficiency policies, and the formation of a society focused on energy conservation [3]. The country pays considerable attention to the revolutionary changes in the field of energy supply. Based on the security and diversification of domestic energy supply, the government is taking steps forward to promote the clean and efficient use of coal, develop other energy sources and at the same time strengthen the energy transmission and distribution network, as well as build a storage network. China is advancing its energy technology programs by moving to a green and low-carbon economy. By encouraging the innovations in technology, industry, and business, China seeks to make innovation a new engine in the process of modernizing the industry. This contributes to the revolutionary changes in the energy system, which include the manufacture of energy products, increasing effective competition, compliance with the mechanism of a market economy, changing energy regulation procedures, and improving the system of energy legislation [15].

Ukraine case. The most representative cases are those countries that have military conflicts in their territory or are involved in and had an impact on their energy security as a result of this. A good example is Ukraine. Since 2015, Ukraine, in its national security strategy, has considered "actions to block Ukraine's efforts to counter the monopolization of strategic sectors of the national economy by Russian capital, to eliminate dependence on monopoly supplies of critical raw materials, especially energy resources", as one of the urgent threats to Ukraine's national security. The Russian conflict had a great impact on the energy security of Ukraine, based on the following existing threats to the country:

- Excessive dependence on energy imports;

- Insufficient level of diversification of energy supply sources and technologies;

- Limited use of own energy potential and new technologies;

- Low fuel and energy efficiency;

- Distortion of market mechanisms in the energy sector;

- Criminalization and corruption of the energy sector;

- Ineffective energy efficiency and energy supply policy.

The current structure of the energy balance and the dynamics of electricity consumption per capita are presented in Figures 3 and 4, respectively. 


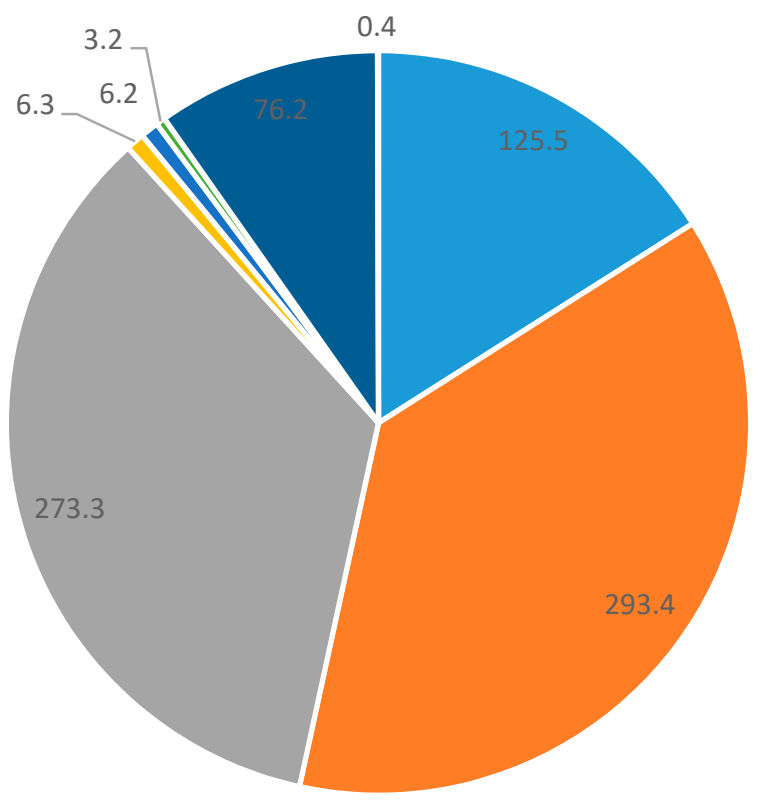

- Oil Consumption - TWh

- Gas Consumption - TWh

- Coal Consumption - TWh

- Hydro Generation - TWh

- Solar Generation - TWh

- Wind Generation - TWh

- Nuclear Generation - TWh

- Geo Biomass Other - TWh

Figure 3. The energy consumption resource distribution in Ukraine in 2020 (according to the data source [14]).

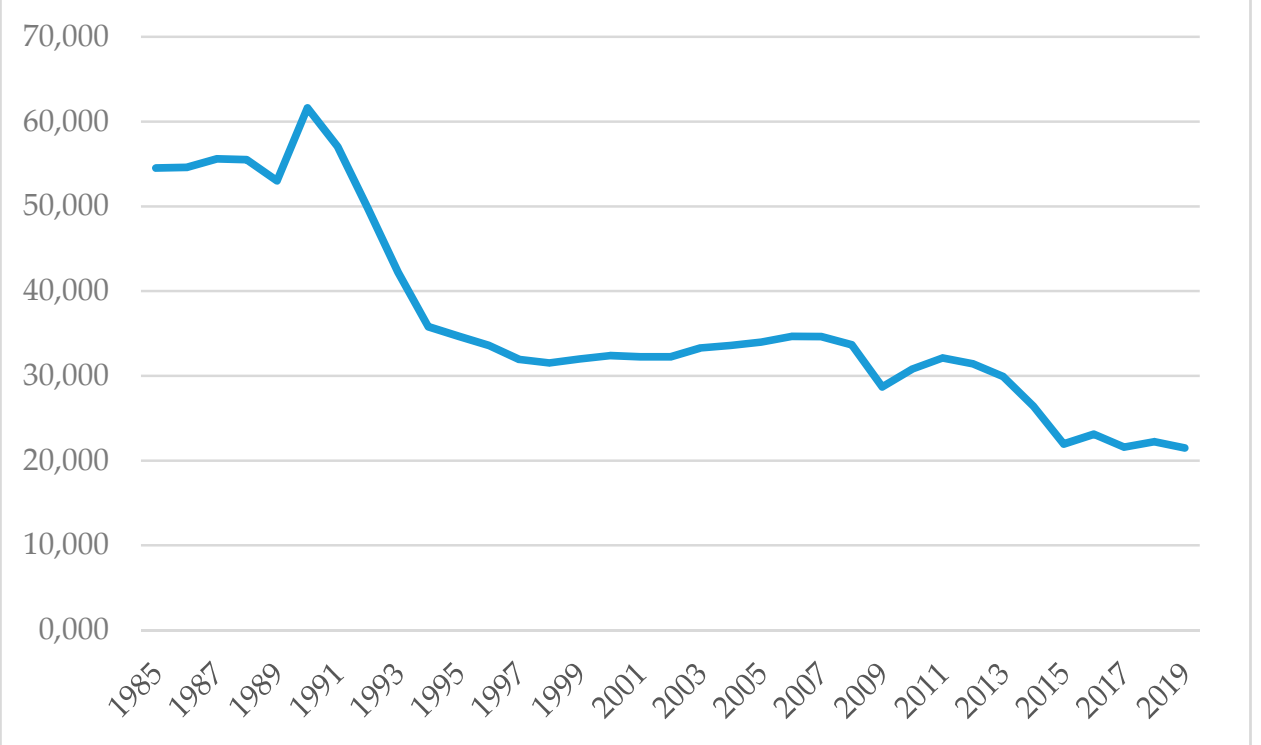

Figure 4. Energy consumption per capita (kWh) in Ukraine (according to the data source [14]).

Norway case. This state is one of the world's largest energy exporters and plays a leading role in promoting global energy security. At the same time, this country is fully committed to environmental sustainability, based on a unique set of resources: hydropower, oil, and new renewable energy sources, such as wind energy and biomass. It is also important to note that the country does not use nuclear energy as an energy source at all. Norway is one of the world's largest exporters of oil and natural gas, ranking ninth in terms of net exports of oil and oil products and third in gas exports in the world at the end of 2019-2020. However, oil and gas play significantly smaller roles in the country's 
domestic energy consumption, as more than $95 \%$ of natural gas and more than $75 \%$ of the oil produced in Norway are exported.

Norway is still one of the largest energy exporters in the world and is increasing its energy production and exports every year. As one can see from the energy balance, the largest share of energy production by sources falls on hydropower; this area is now promising for Norway and the country is actively developing it (Figure 5). During the last decades, Norway has tried to decrease the consumption level per capita with the help of the more efficient use of the resources (Figure 6).

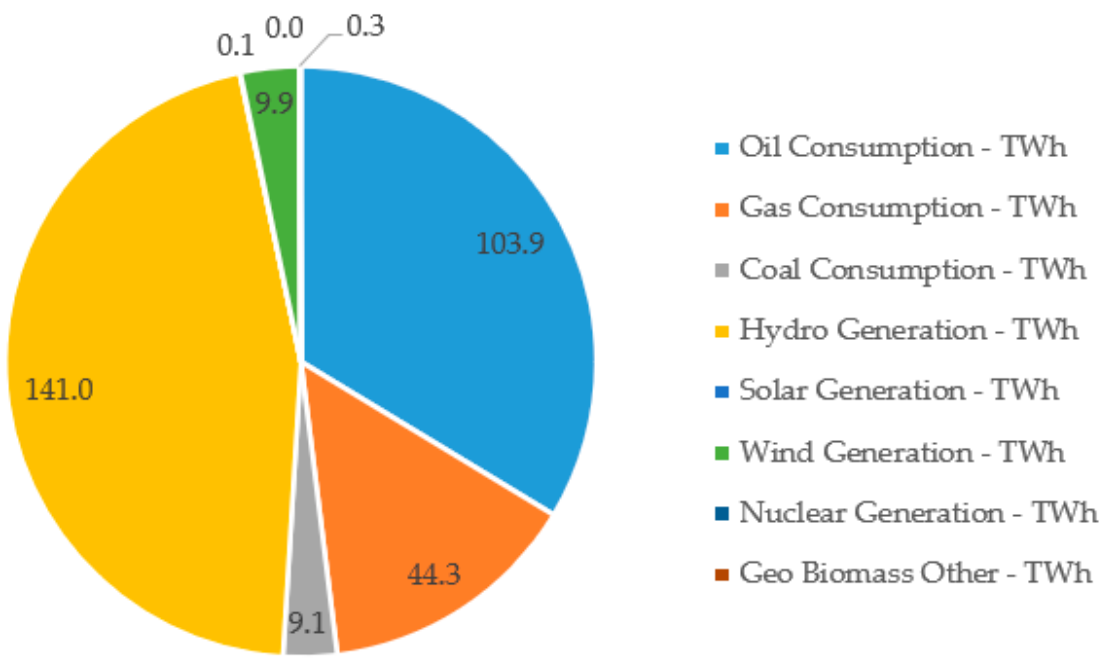

Figure 5. The energy consumption resource distribution in Norway in 2020 (according to the data source [14]).

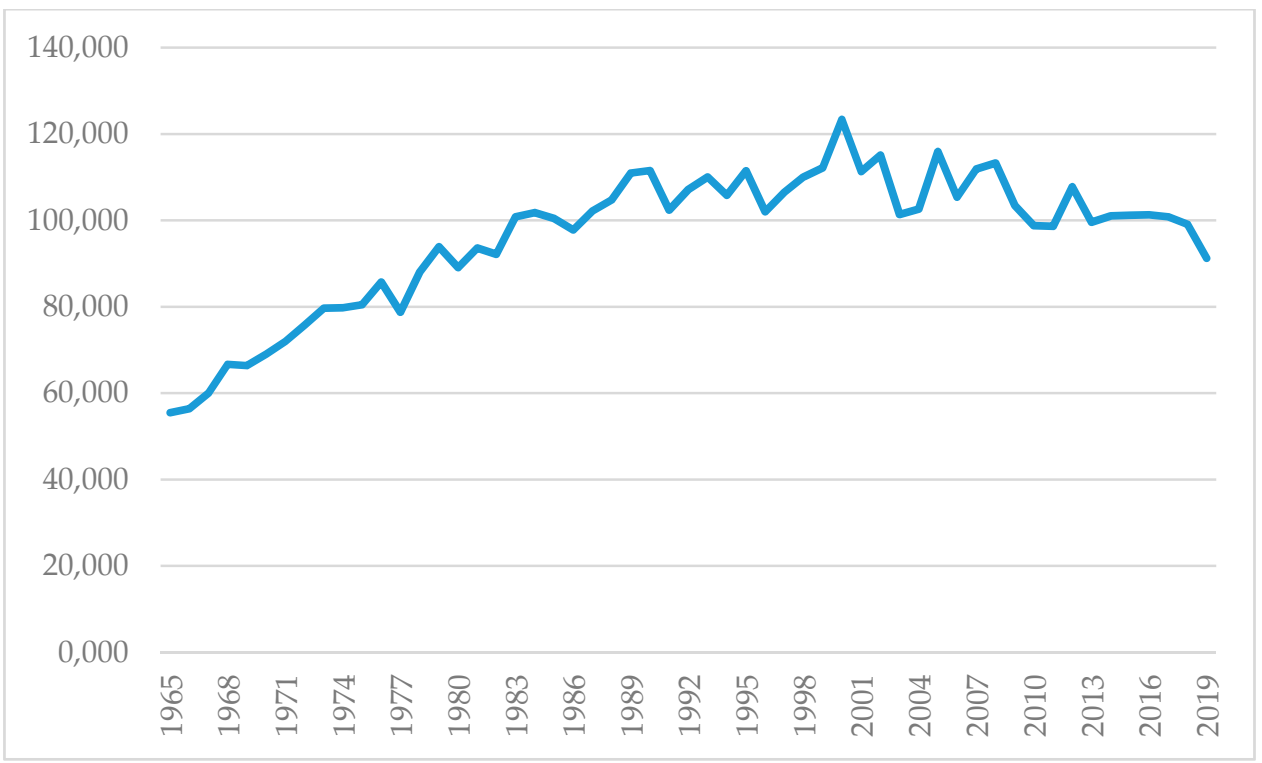

Figure 6. Energy consumption per capita (kWh) in Norway (according to the data source [14]).

U.S.A. case. The United States is unable to curb its dependence on imported oil, although solutions are being offered from time to time. In particular, most vehicles in the United States run on fuel made from imported oil.

At the same time, there is widespread support in the United States for the World Energy Committee's view that energy security is seen as the assurance that a country will have access to energy in the quantities and qualities that are needed in these economic conditions. Thus, the emphasis is removed from the operation of own fuel and the use of 
imported energy is considered as normal in terms of energy security. There is no consensus on this, but the fact remains that the United States does not stop relying on imported energy.

The importance of energy security in modern conditions for the United States demonstrates the impact of energy security on the foreign policy of the state as a whole. Thus, the United States is actively defending its interests in the Middle East, in its quest to ensure profitable and stable oil imports from the region [16]. The government is also paying attention to the development of alternative energy sources, such as the development of the country's internal fields and the gradual transition to renewable energy sources [17]. An important element that has an impact on energy security is the environment, so the United States is gradually reducing the share of the sources of thermal electricity that pollute the environment (Figure 7). However, oil is still the main source of energy, followed by gas (Figure 7). Renewable energy sources still occupy a relatively small share of the spectrum, but their share is gradually increasing.

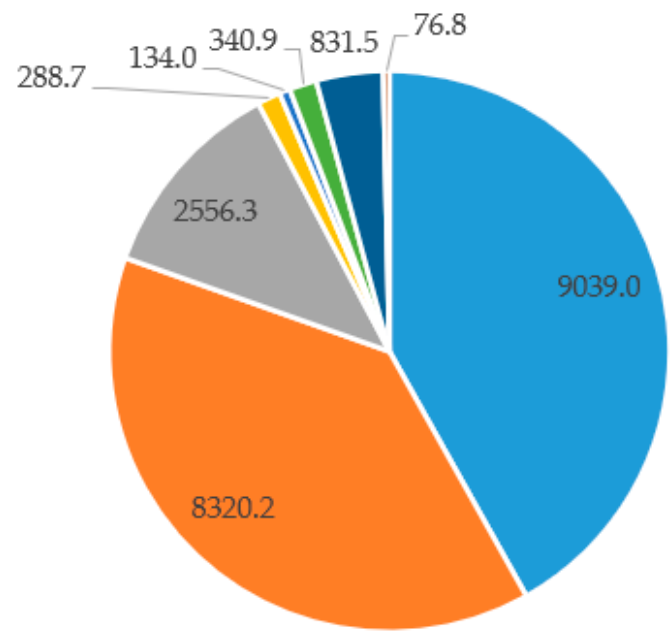

- Oil Consumption - TWh

- Gas Consumption - TWh

- Coal Consumption - TWh

- Hydro Generation - TWh

- Solar Generation - TWh

- Wind Generation - TWh

- Nuclear Generation - TWh

- Geo Biomass Other - TWh

Figure 7. The energy consumption resource distribution in the U.S.A. in 2020 (according to the data source [14]).

Figure 8 shows that U.S. electricity consumption remains stable per capita; needs are growing in proportion to the rate of the population growth rather than exceeding them, as was the case at the end of the last century, which allows for the conclusion that ensuring energy security in the country is quite achievable.

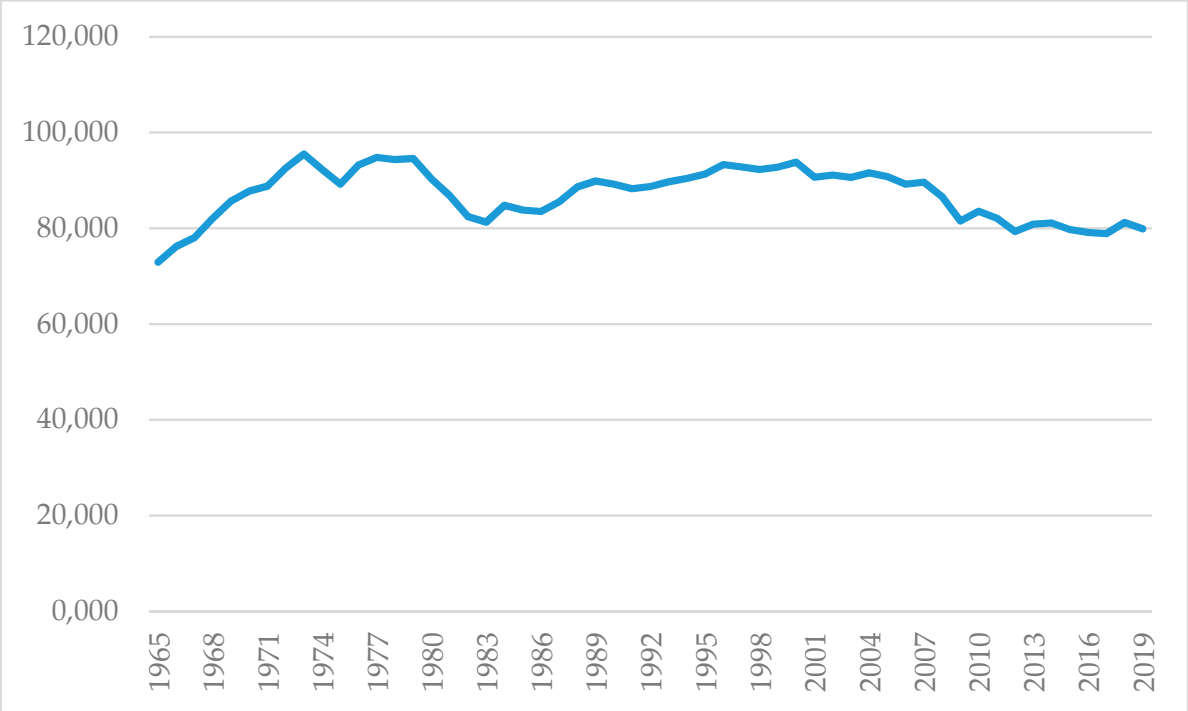

Figure 8. Energy consumption per capita (kWh) in the U.S.A. (according to the data source [14]). 
Military conflicts and the energy situation in the world. Military conflicts over energy issues have existed in the world for a long time. The reason is that the modern energy world is characterized by deep disparities: we can observe a dissonance between the reserves of resources (such as oil and gas) in different countries (Figure 9).

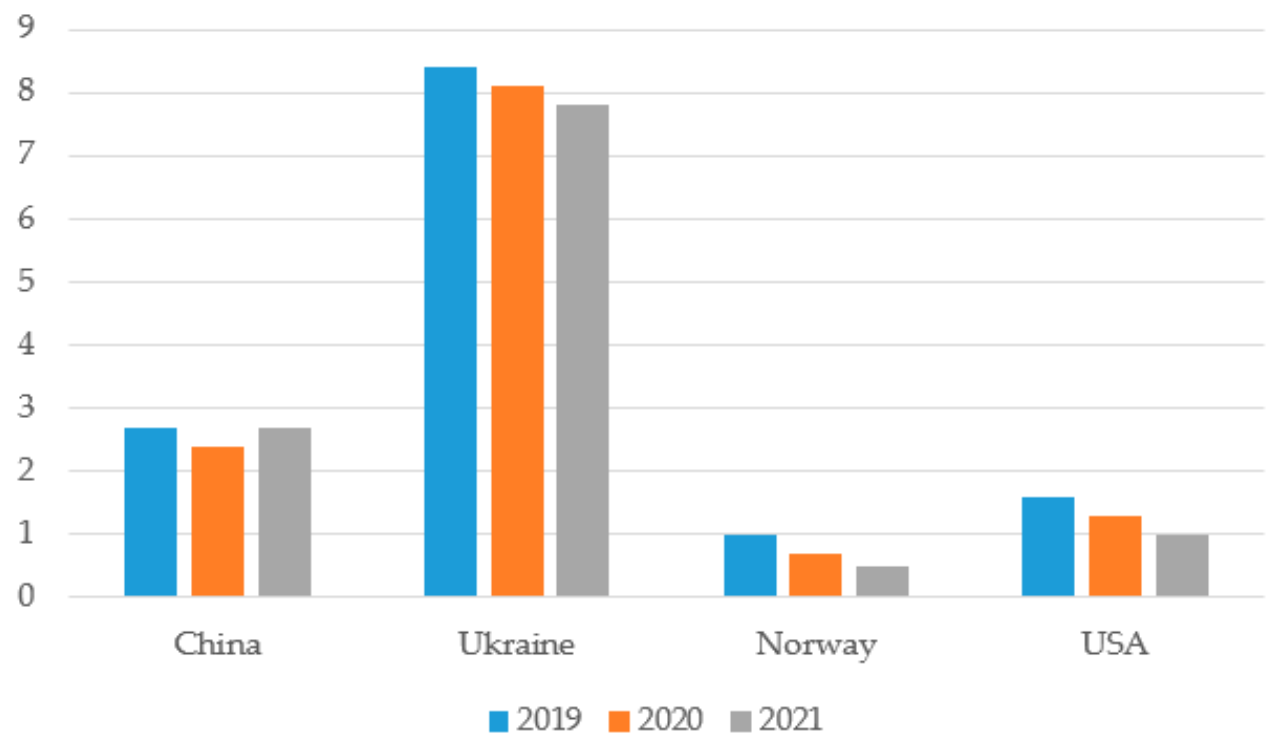

Figure 9. External interventions index (according to the data [18]).

Unfortunately, the worst situation is observed in Ukraine (Figure 9). Norway has the best situation not only among the proposed countries, but also in general among all the countries in the world rankings.

In addition to the different levels of resource security, there may be tensions and uncertainties between countries, and actually, all continents demonstrate the same (see Table A1 [19-25]). The coronavirus further deepened the negative aspects and exacerbated the military conflicts that arose over energy issues [26]. By analyzing the literature, one can see the following origins of energy wars [27,28]: we live in an energy-oriented world, in which the control over oil and gas resources (and their means of delivery) turns into a form of geopolitical influence for some and economic vulnerability for others [29]. However, most researchers consider geo-economic positions and sustainability as the prerequisite for energy power/fragility [30]. Additionally, there is the opinion that conflicts and military actions cause energy security more soundly, but not the opposite [31,32]. Indeed, Samaras et al. [32] insist and provide ground evidence that energy considerations are essential to the missions of armed forces worldwide. The interaction between military energy issues and non-military energy matters is not often explicitly treated in the literature or media, although the issues concerning clean energy have increased the awareness of this interaction. This point of view is not singular [33-35] and as well there are lessons of the cold war [36].

A good example of the symbiosis between military and energy conflicts is Russia's hybrid campaign against Ukraine, which combines supply disruptions, cyber-attacks, economic and political pressure, and disinformation efforts to undermine the country's energy security and create political instability. Russia's most destructive action was to cut off gas supplies in 2009, but the attacks continue and are becoming increasingly complex and threatening. A good example is the December 2015 Black Energy cyberattack on a power plant in western Ukraine, which cut off electricity supplies to nearly a quarter of a million residents for six hours. After that, a year later, there was a more complex attack on the power supply network of the capital, the city of Kyiv, using malware CrashOverride/Industroyer. This attack was not as long and large-scale as the previous one, but it posed a much greater threat: it was aimed at disabling electrical safety relays that protected the main power equipment. If analysts had not detected this attack in time, in its last phase, in addition to a 
short interruption of electricity supply, there could have been the physical destruction of very expensive equipment, which is difficult to replace [37].

However, the research analysis of the correlations and casualties of national security and energy security is not yet completed and has ample research gaps to be covered (Table A2). For example, there is no research on the topic that uses the mathematically grounded apparatus and considers different continents simultaneously. Even the most explicit attempt to evaluate energy security as a component of the national security of the country [2] has a lack of objective assessments, as it is based on the weighted indices. The majority of studies that declared the ground mathematic approach to the energy security index and its correlation to security are concentrated on one state and its internal sustainability indicators (i.e. Fang et al; Bompard et al; Mottaghi \& Davoudi [38-40]) or narrowed the security issues towards macroeconomic security (i.e., Stavytskyy et al [1]). At the same time, despite the differences in the approaches and the scopes, the studies are synchronic in the results that are concentrated on the macroeconomic policy and energy security recommendations. Just a few researches are highly cited and prominent in their results that discuss the impacts on and recommendations to national security $[40,41]$. The paper addresses this research gap by the means of econometric modeling, in particular. Overall, it is concluded from the Literature Survey that despite the assumption of clarity in considering both types of security in their dual relations by actors/countries, there is a great shortage of researches published that use a mathematical approach and calculative assessments for more than one state at a time and for a long time series [42,43].

\section{Methodology}

The main point of the methodology is to find the most representative indicator to reflect the topic of the research: the correlation between energy security and national security. To answer this, the most known existing indexes of energy security, ecology security, economic security, and national security are considered (Table 1). The search reflects whether the national security indexes of the main energy players contain energy security in its calculative methodology.

The analysis presented (Table 1) reveals that despite the existing geopolitical dichotomy, the national security indexes do not consider energy security in regards to the whole possible scale, and mostly only from the position of consumption. However, if energy security is being considered, the resources and production of energy are kept away from the national security. The fact is that the main energy players do not reveal energy security as a priority of their national security [44] (i.e., U.S.A., Germany [45], and France). Furthermore, NATO considers main objectives of energy security, such as the monitoring and evaluation of the situation in industry energy security; assistance of allies in security; observation of sea corridors and measures to respond to possible threats; and operations to prevent attacks based on energy infrastructure.

Thus, there is the logical necessity to consider the energy indices as the next step of the research (Table 2). A quite obvious fact is that this type of index is global and not primarily devoted to the security of the particular state, but to the cross-state comparisons. Therefore, energy security should be directly attributed to the areas of national security that ensure the realization of one of the fundamental national interests-the sustainable development of the national economy, society, and the state to ensure the growth of quality and quality of life. At the same time, energy security also participates in ensuring other national interests-state sovereignty and independence. 
Table 1. World indexes of national security.

\begin{tabular}{|c|c|c|c|}
\hline Title (State) & Short Description & Formula & Energy Security Component \\
\hline National Security Index (NSI) (India) [46] & $\begin{array}{l}\text { The NSI is an average of five other indices: the Human } \\
\text { Development Index (HDI), the R\&D Index, the Gross } \\
\text { Domestic Product Performance Index, the Defense } \\
\text { Expenditure Index, and the Population Index. }\end{array}$ & $\begin{array}{l}\text { The Indian National Security Index consists of: } \\
30 \% \text {-defense capacity } \\
20 \% \text { - economic power } \\
20 \% \text { - technology } \\
20 \% \text { - the effective population } \\
10 \% \text { - energy security. }\end{array}$ & $\begin{array}{l}\text { The NSI does not cover other aspects of national } \\
\text { security, such as the quality of governance, the } \\
\text { environment, and the availability of } \\
\text { natural resources. }\end{array}$ \\
\hline Chinese National Power (CNP) (China) & $\begin{array}{l}\text { China's CNP index is the sum of a country's natural } \\
\text { resources, domestic economic capacity, external economic } \\
\text { capacity, scientific and technological capacity, level of } \\
\text { social development, military capacity, government } \\
\text { administrative capacity, and foreign or } \\
\text { diplomatic capacity. }\end{array}$ & 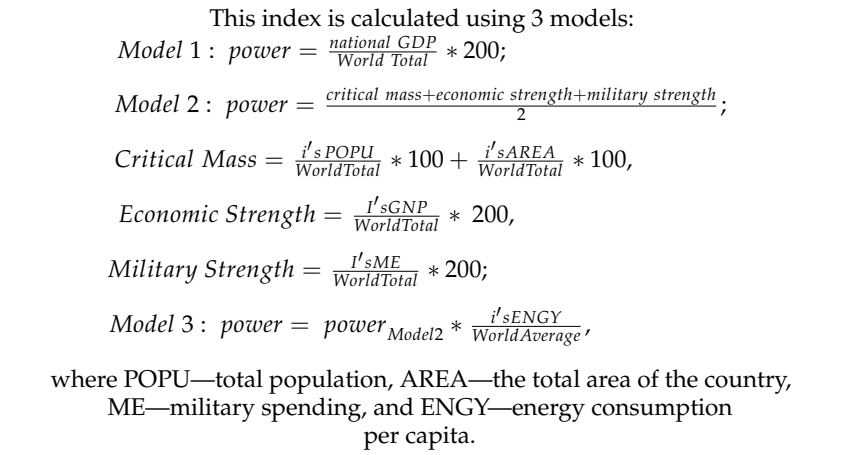 & Energy consumption per capita is considered. \\
\hline $\begin{array}{l}\text { Integral Index of Economic Security of the } \\
\text { Country (Ukraine) }\end{array}$ & $\begin{array}{l}\text { One of the main components of national security. The } \\
\text { index consists of } 9 \text { weighted average sub-indices } \\
\text { (components of economic security): } \\
\text { (1) Industrial safety; } \\
\text { (2) Demographic security; } \\
\text { (3) Energy security; } \\
\text { (4) Foreign economic security; } \\
\text { (5) Investment and Innovation security; } \\
\text { (6) Macroeconomic security; } \\
\text { (7) Food security; } \\
\text { (8) Social security; } \\
\text { (9) Financial security. }\end{array}$ & $\begin{array}{l}\text { The calculation of the integrated indicator for each security area is carried out } \\
\text { according to the following formula: } \\
\qquad I_{m}=\sum_{i=1}^{n} d_{i} y_{i} \\
\text { where } I_{m} \text { is the aggregate indicator/subindex of the } m \text {-th sphere of economic } \\
\text { security; where } m=(1,2,3, \ldots 9) \text {, } \\
\text { di is the weighting factor that determines the degree of contribution of the } \\
i \text {-th indicator to the integrated index of the component of economic } \\
\text { security; and } \\
y_{j} \text {-normalized is the score of the } i \text {-th indicator. } \\
\text { The integrated indicator of economic security of Ukraine }(I) \text { is generally } \\
\text { calculated by the following formula: } \\
\qquad I=\sum_{m} d_{m} I_{m} \\
\text { where dm is the weighting factor that determines the degree of contribution } \\
\text { of the indicator/sub-index of the m-th sphere of economic security to the } \\
\text { integrated index of the economic security of Ukraine; } I_{m}-\text { aggregate } \\
\text { indicator/subindex of the } m \text {-th sphere of economic security, } \\
\text { where } m=(1,2,3 \ldots 9) \\
\text { CINC }=\frac{T P R+U P R+I S P R+E C R+M E R+M P R}{6}\end{array}$ & $\begin{array}{l}\text { The component of the economic security index. } \\
\text { There is no official energy security index of national } \\
\text { security index. }\end{array}$ \\
\hline
\end{tabular}


Table 1. Cont.

\section{Title (State)}

Composed Index of National Capability (USA)

Statistical assessment of the national power of the state, the calculation of which the average percentage of six different world indicators is used.
Formula

were TPR = total population ratio, UPR = urban population ratio,

$\mathrm{SPR}=$ coefficient of production of cast consumption factor, $\mathrm{MER}=$ military expenditure ratio, and $\mathrm{MPR}=$ army ratio.
Energy Security Component

The primary energy consumption facto

Assessed for the world tensions, the project is finalized in 2020.

Energy security is not directly considered.

e security apparatus indicator considers the security threats to a state, such as bombings, attacks and battle-related deaths, rebel movements, mutinies, coups, or terrorism. The security apparatus also takes into account serious criminal factors, such as organized crime and homicides, and perceived trust more the threats in the state. The average for 2021 based on 173 countries was 5.29 index points.
Security Threats Index [47]

The part of the Fragile State Index calculated by the Globa Economy portal.

Table 2. Energy security indices.

\section{Title}

International Energy Security Risk Index [48]

Measured risks to energy security in different countries. The index calculates the risk estimates for the United States and 74 other countries that make up the group of largest energy consumers [49]. Scores (index values) for these countries are the ratio to the reference index, which is taken as the average for member countries of the Organization for Economic Cooperation and Development (OECD) in 1980 (adopted per 1000).

The World Energy Council reflects the assessment of the efficiency of the country's energy system. Balancing these three goals is a "trilemma" and ensures the prosperity and competitiveness of individual countries. The report presents a comparative ranking of 128 countries. The evaluation of the index is that the

World Energy Trilemma Index [50] effectiveness of individual countries in developing and implementing policies to ensure energy sustainability varies from country to country and region to region.

The World Energy Council recognizes the value of adopting an integrated approach to energy systems to benefit sustainable energy for all.

Developed to assess the real state of availability and quality of the information in the energy sector and to diagnose gaps. The index covers 210 indicators, grouped into 8 categories and based on specific regulatory requirements and best global

Energy Transparency Index [51] disclosure practices. The evaluation is the result of processing open-source data on the functioning and development of the energy sector along the chain "from

\section{Components}

Energy security is not considered. f the global fuel market,

$$
\text { fuel imports, }
$$

energy costs, market prices, and volatility, energy use, electricity sector, transport sector, environment.

The 3 main dimensions: energy security, energy justice, and environmental sustainability. Efficiency indicators include supply and demand, energy availability and accessibility, energy intensity and efficiency, and emissions alated to engy system. Contextul indicaty re broader context of energy eficiency, including the country's ability to provide coherent predictable, and stable policies and regulations, initiate $R \& D$ and innovation, and attract investment.

Balances natural monopolies, supply, reliability and security, consumption reporting, policy, and government. 
Generally, researchers claim that there are the following methods for calculating and characterizing the energy security of the country: the method of scalarization, discriminant analysis, fuzzy set theory, panel regression analysis [52], the Shannon-Wiener and Herfindahr-Hirschman indices, method of monitoring [53], and indicative analysis.

The aim of the present paper and the literature review is to explore the ability to use the econometric methodology to test the statistical ties between the national security indicator and the energy security indicator, as well as to consider the possible factors that could be impactful on both indicators.

The methods of the correlation analyses are adopted to find the list of factors that have the most significant connection between their dynamics of variations and the dependent variable. The regression analysis is applied to assess the level of the indicated impact and to provide a possible forecast for the nearest future on the basis that the general tendencies would stay the same. According to the rules of the econometric analyses, all incorporated variables are tested on the stationarity and normality by ADF and Jeark-Berr tests, appropriately.

Thus, we fully follow the econometric analyses stages that are classically presented in [54]:

1-Consideration of the factors that could be impactful, and a declaration of the dependent variable and specification of the model.

As the literature review revealed, there was a significant shortage of indexes (that represent the dual subject-national security and energy security) that could be demonstrative, long-term, and equally available for the list of considered countries; therefore, we use the available variables in the research by ESRI (Energy Security Risk Index [48], Table 3), ESI, and STI. The index of economic security (ESI) (based on Stavytskyy, 2018 [55]) is subsequently considered. According to Stavytskyy's method, 1 is a Central European branch marker. If a country's security index is higher than 1 , its development is currently better than the European average, and if it is lower than 1, the country is inferior to the level of economic security currently achieved on average in Europe. There is no representative in the geography and in the time perspective index to reflect the national security, so the closest to it is chosen - the Security Threat Index (STI) that is the component of the Fragile State Index (keep in mind that the higher volumes of this index depict the threatening situation and fragile security). Additionally, energy security is presented by the Energy Security Risk Index (ESRI), which has the same representation-the higher volumes demonstrate the higher risk, thus the less secure the situation. However, the official sources have a sginificant lack of data that are not presented for the whole diapason, 1990-2021, for all the analyzed countries.

Table 3. Correlation analysis result.

\begin{tabular}{cccc}
\hline & ESRI & ESI & STI \\
\hline ESRI & & & \\
ESI & Ch $(\mathrm{r}=-0.51)$, USA $(\mathrm{r}=-0.70)$ & \\
STI & UKR $(\mathrm{r}=0.99)$ & \\
& Ge $(\mathrm{r}=0.69)$ & U.S.A. $(\mathrm{r}=0.80)$ \\
& USA $(\mathrm{r}=-0.91)$ & \\
\hline
\end{tabular}

Then, the logic of the research is to consider the linear regression dependencies between the indices.

2-The analyses of correlations. The diapason of the correlation index is -1 to 1 , revealing negative and positive dependencies, correspondingly. Since the correlation index was higher than \pm 0.7 , we can observe a strong connection in the dynamics between the couple of indices considered. Thus, the increase in one could be reflected in the increase in the other, expectedly (positive correlation), or vice versa-opposite directions (negative correlation).

3-Modeling stage, where linear dependency is calculated to see the level of dependency between factors, to see elasticities and the scale of this dependency. 
The application for all model calculations is Eviews software. The estimation output in it demonstrates not just the final calculations of coefficients of the linear regression model, but also the verification criteria for its efficiency (significance of results, t-criteria), reliability (Adjusted R-sq), and adequacy (F-criteria).

4-Forecasting and policy recommendation stage, if necessary.

\section{Results}

To find the mathematical approval of the possible similarities in the main indices' dynamics, the correlation analysis is applied (Table 3).

Table 3 accumulates only the statistically significant results. Here, one can see that the energy index is significant (the significance is measured by the value of the correlation coefficient and t-statistics of it) for the economic security indices only in China and the U.S.A. from the list of analyzed countries, but it is significant for the security threat index in all the selected countries, except for Germany. According to the received results of the correlation analyses of the 1991-2020 data set, there is no significant correlation for the indices of this country.

It must be taken into account that there is a lack of any index that reflects national security for the long period and the cross-state comparisons. Economic security seems to be considered as one of the principal components of any national security system and as the depictor of the nation's well-being. In Ukraine, the minimal value of the economic security index is 0.67 , the maximal is 0.95 (Figure 10). It should be noted that the dynamics of the economic security indices in European countries are gradually leveling off (Figure 11). In our opinion, this is because new technologies are actively involved in the countries; there is a constant optimization of energy supply chains, the introduction of digitalization. As a result, leading countries may lose their dominance and outsider countries can quickly take the lead by introducing new approaches.

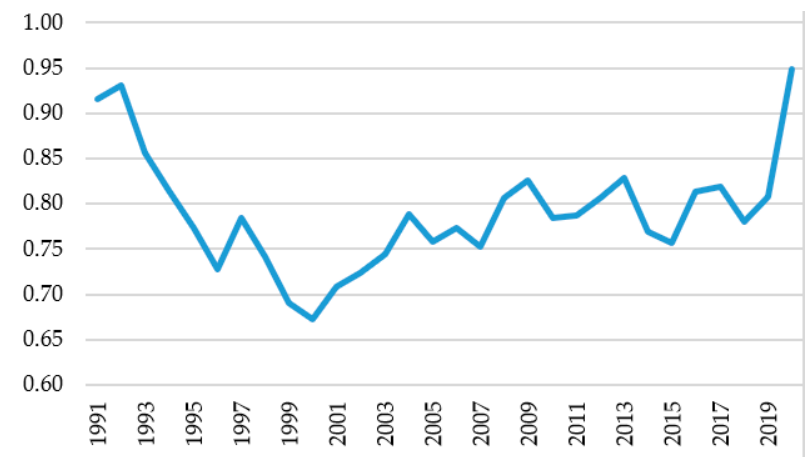

Figure 10. Index of economic security for Ukraine.

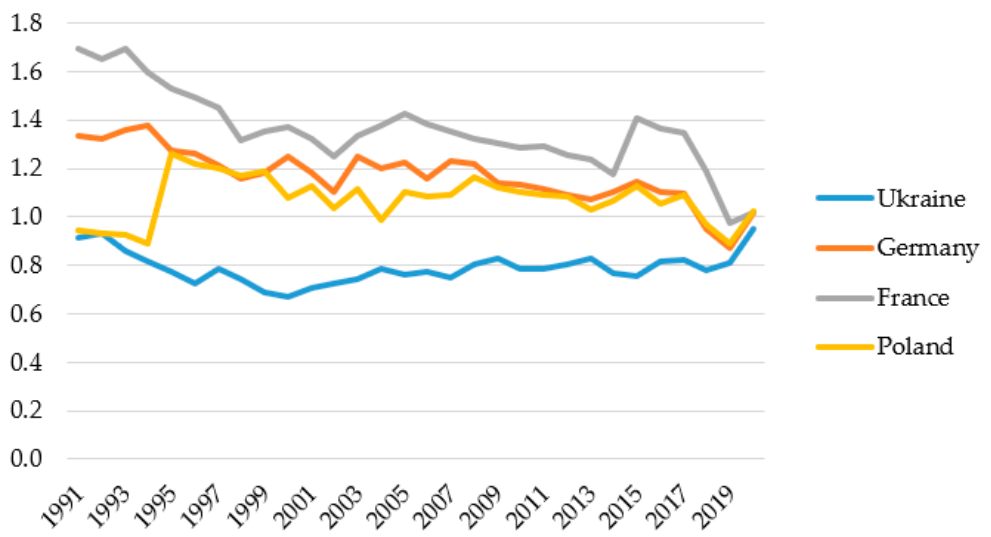

Figure 11. Comparative dynamics of economic security indices of Ukraine, Germany, France, and Poland during 1991-2020. 
One of the European outsiders for a long time was Ukraine, which in recent years has taken significant steps to improve living standards (Figure 12). Due to the opening of borders in Ukraine, which resulted in the significant migration of the population, the competition for labor resources intensified, which contributed to both higher wages and the automation of production and provision of services. Due to this, Ukraine currently has a quite prominent position in Europe in terms of the convenience of banking services, digitalization of public services, and automation of production, which will significantly increase the level of economic security components. The optimization of supply chains is particularly rapid in the energy sector, which greatly contributes to Ukraine's energy independence.

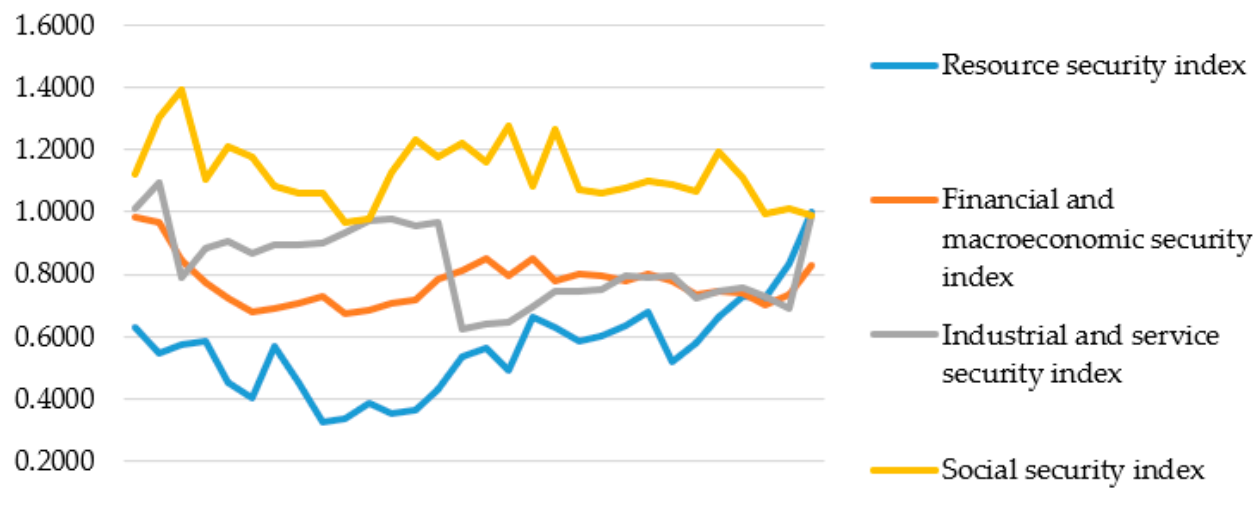

0.0000

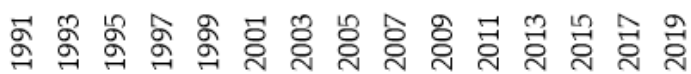

Figure 12. Dynamics of structural components of the economic security of Ukraine.

As the next stage, the assessment of the energy security factors on the economic security index is considered through the correlation and regression analyses for Ukraine (1991-2019).

Each cell (Figure 13) corresponds to the value of the correlation between the indicators specified in the names of the rows and columns of the matrix. Blue corresponds to a large positive correlation, and red corresponds to a large negative correlation. Therefore, having analyzed the obtained values, first of all in the first column that indicates the correlation of all the selected indicators with the EB index, the research highlights those that have the greatest value and, accordingly, the strongest influence.

Thus, we selected indicators on the basis of the correlation analyses (Figure 14):

- Electric power consumption (kWh per capita);

- Fuel imports (\% of merchandise imports);

- Adjusted savings: energy depletion (\% of GNI);

- Electric power transmission and distribution losses (\% of output);

- Alternative and nuclear energy (\% of total energy use);

- Electricity production from renewable sources, excluding hydroelectric (\% of total);

- Adjusted net savings, including particulate emission damage (\% of GNI);

- Adjusted savings: carbon dioxide damage (\% of GNI);

- Access to electricity (\% of the population);

- Access to electricity, rural (\% of rural population);

- Access to electricity, urban (\% of urban population). 


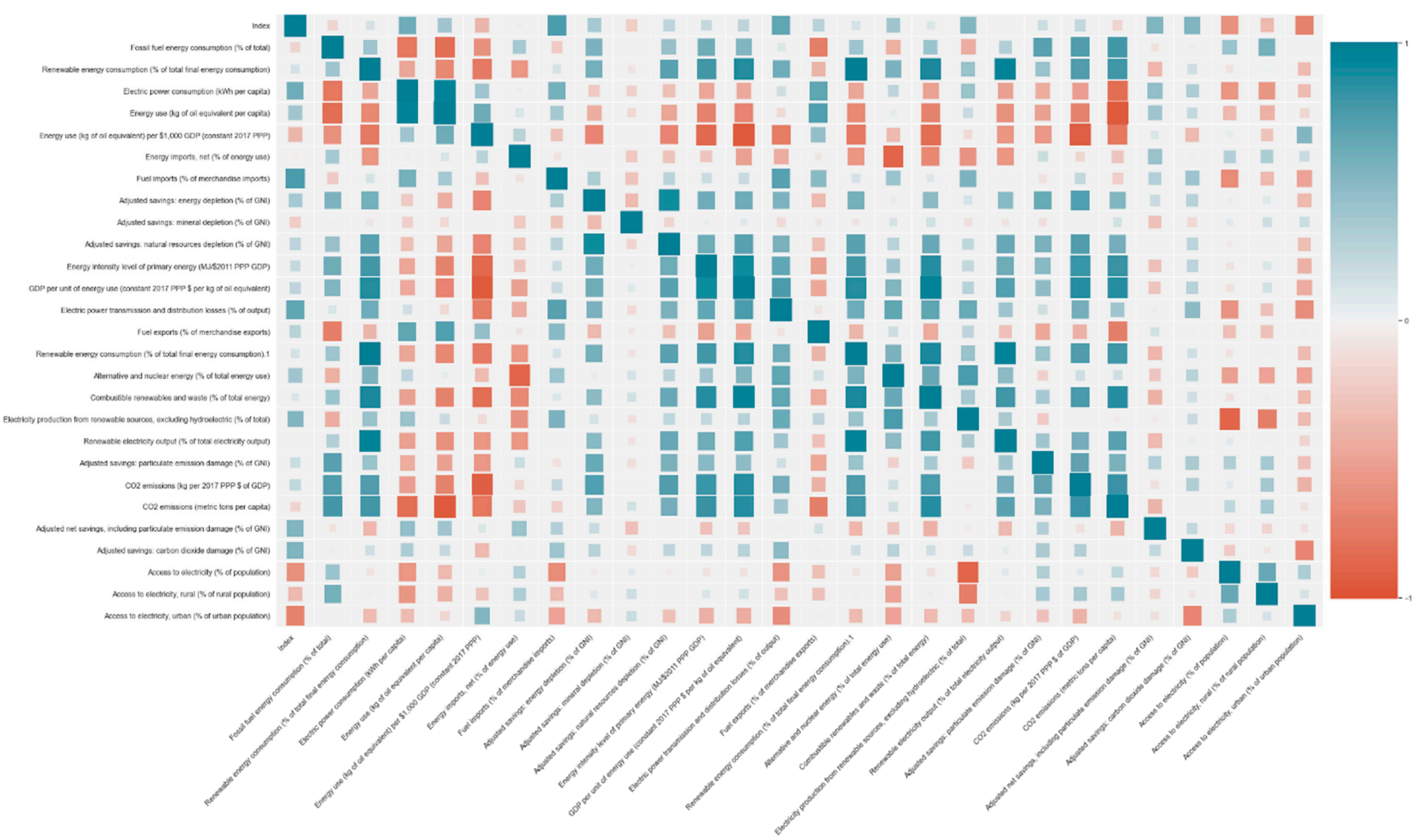

Figure 13. Correlation matrix: between factors (Python representation). 


\section{Index \\ Fossil fuel energy consumption ( $\%$ of total) \\ Electric power consumption (kWh per capita) \\ Energy use ( $\mathrm{kg}$ of oil equivalent per capita)}

Renewable energy consumption ( $\%$ of total final energy consumption)

Energy use ( $\mathrm{kg}$ of oil equivalent) per \$1,000 GDP (constant 2017 PPP) Energy imports, net ( $\%$ of energy use) Fuel imports ( $\%$ of merchandise imports) Adjusted savings: energy depletion ( $\%$ of GNI) Adjusted savings: mineral depletion ( $\%$ of GNI) Adjusted savings: natural resources depletion ( $\%$ of GNI) Energy intensity level of primary energy (MJ/S2011 PPP GDP) GDP per unit of energy use (constant 2017 PPP \$ per $\mathrm{kg}$ of oil equivalent) Electric power transmission and distribution losses ( $\%$ of output) Fuel exports ( $\%$ of merchandise exports)

Renewable energy consumption ( $\%$ of total final energy consumption). 1 Aternative and nuclear energy ( $\%$ of total energy use) Combustible renewables and waste ( $\%$ of total energy) Electricity production from renewable sources, excluding hydroelectric ( $\%$ of total) Renewable electricity output ( $\%$ of total electricity output) Adjusted savings: particulate emission damage ( $\%$ of GNI) CO2 emissions ( $\mathrm{kg}$ per 2017 PPP $\mathrm{S}$ of GDP) CO2 emissions (metric tons per capita) Adjusted net savings, including particulate emission damage ( $\%$ of GNI) Adjusted savings: carbon dioxide damage ( $\%$ of $\mathrm{GNI}$ ) Access to electricity ( $\%$ of population) Access to electricity, rural ( $\%$ of rural population) Access to electricity, urban ( $\%$ of urban population)

Figure 14. Correlation matrix: impact of factors on the dependent indicator.

Thus, the most appropriate model for Ukraine to determine the list of energy security indicators that could be highly impactful on the economic security index is the following: (assessments are realized in Eviews) (Figure 15). 


\begin{tabular}{|c|c|c|c|c|}
\hline Variable & Coefficient & Std. Error & t-Statistic & Prob. \\
\hline ELECTRIC_POWER_CONSUMPTION. & 0.054498 & 0.018646 & 2.922798 & 0.0074 \\
\hline ELECTRIC_POWER_TRANSMISSION... & 0.131928 & 0.031836 & 4.144045 & 0.0004 \\
\hline ADJUSTED_NET_SAV̄INGS_INCLUDI.. & 0.041195 & 0.010047 & 4.100117 & 0.0004 \\
\hline ACCESS_TŌ_ELĒETRICITY__URBAN.. & -1.125288 & 0.419582 & -2.681924 & 0.0130 \\
\hline 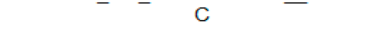 & 1.770618 & 0.459850 & 3.850422 & 0.0008 \\
\hline R-squared & 0.849416 & \multirow{7}{*}{\multicolumn{2}{|c|}{$\begin{array}{l}\text { Mean dependent var } \\
\text { S.D. dependent var } \\
\text { Akaike info criterion } \\
\text { Schwarz criterion } \\
\text { Hannan-Quinn criter. } \\
\text { Durbin-Watson stat }\end{array}$}} & 0.784208 \\
\hline Adjusted R-squared & 0.824318 & & & 0.057387 \\
\hline S.E. of regression & 0.024053 & & & -4.461498 \\
\hline Sum squared resid & 0.013886 & & & -4.225757 \\
\hline Log likelihood & 69.69171 & & & -4.387667 \\
\hline F-statistic & 33.84480 & & & 1.777105 \\
\hline Prob(F-statistic) & 0.000000 & & & \\
\hline
\end{tabular}

Figure 15. Eviews linear regression assessment output.

For the percentages detecting the impact and the normality of the model, the model is transformed in the log-log model (Figure A1). Thus, the model is quite significant and appropriate (MAPE is quite low) (Figure A2). The verification of the model is confirmed; it has normality in the residuals, no autocorrelation, no heteroskedasticity, is stable and appropriate, and furthermore significant.

Similar stages for the econometric assessment between the energy security indicators and energy security index are proposed for Germany, the U.S.A., and China, as quite prominent energy players in the world.

By analyzing Figure 16, we observe that in the recent years (2013-2019) there is a noticeable tendency to increase the overall index of economic security. In our opinion, this is explained, first of all, by the rapid growth of the resource security index and some of its indicators, in particular, as indicators of attracting new energy sources, indicators of resource consumption, and indicators of pollution due to mining activities. However, in many respects, this growth was not due to the qualitative changes in these areas, but due to the problem in recent years of the incomplete availability of information for countries around the world and, in particular, Germany. Given the methodology for calculating the indices, the values of the components of the indicator equal to 1 are used for the years for which there was no information. Thus, there has been a sharp increase in recent years. Despite this, all other indicators also increased, which also indicates qualitative changes.

1.20

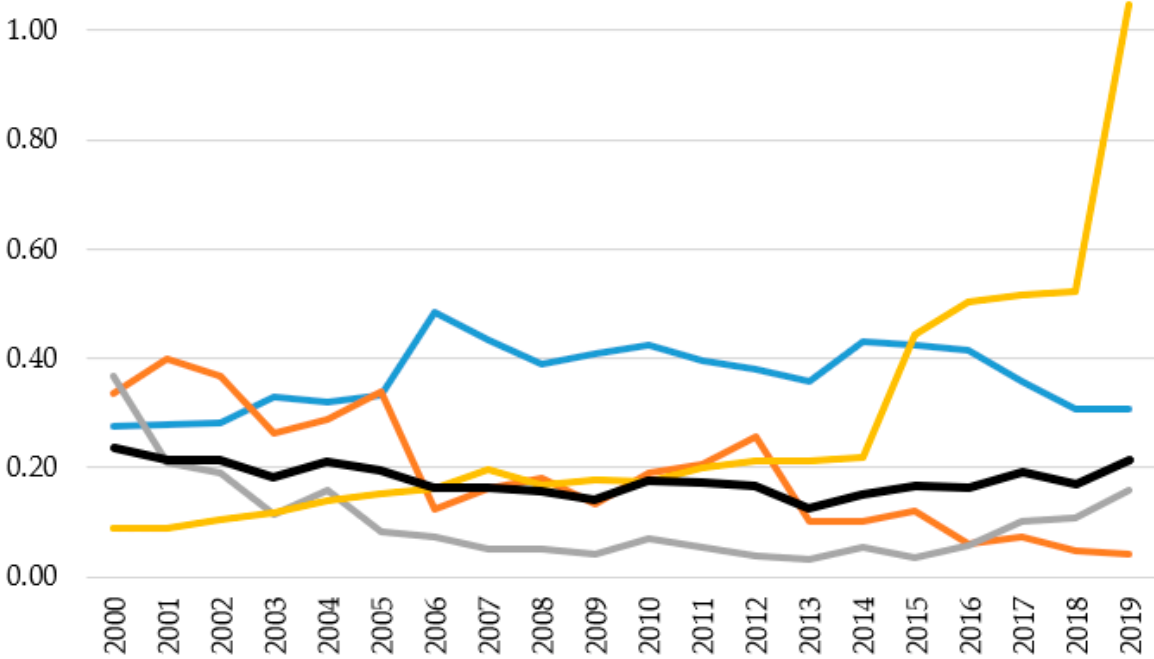

Figure 16. Dynamics of the structural components of the index of economic security in Germany: blue line-social security index, orange-industrial and service security index, grey-financial and macroeconomic security index, yellow-resource index, and black-economic security index. 
By analyzing the changes over 20 years for the U.S.A. (Figure 17), one can immediately notice a substantial and very sharp decline in the index of industrial and service safety, which occurred at the beginning of the century. In 2001, it reached its peak, after which it decreased very rapidly. Such drastic changes could be caused by the terrorist attack that took place in the United States in 2001. This terrible event had a very strong impact on the country and the world in general, destabilizing the situation and causing a huge reaction in the world. Considering the economic security index in general, one can say that throughout the analyzed period it was uniform and did not show any strong changes in the direction of growth or decline. However, there has also been a marked decrease in the period since 2001. The chart of the dynamics of the financial and macroeconomic security index is also interesting. There is a clear decline in 2009 , which was caused by the global economic crisis that originated in the United States and gave impetus to the entire world economy. Other indices did not change sharply during 2000-2020.

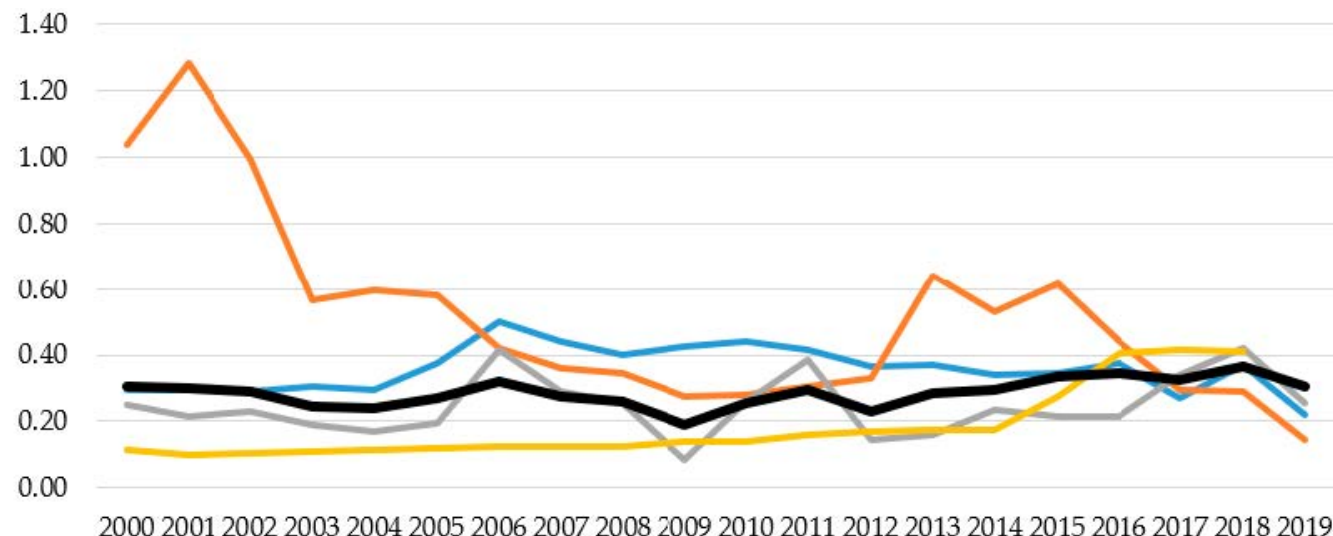

Figure 17. Dynamics of the structural components of the index of economic security for the U.S.A.: blue line-social security index, orange-industrial and service security index, grey-financial and macroeconomic security index, yellow-resource index, and black-economic security index.

By analyzing Figure 18, one can say that the economic security index is steadily growing throughout the analyzed period (2000-2018). The trend accelerated in 2015 corresponds to the strengthening of China's economic position in the world economy, the growth of the overall economic security index safety, and some of its indicators, in particular, such as indicators of electricity production from renewable sources and waste, indicators of resource consumption, and pollution indicators that assessed the level of greenhouse gas and $\mathrm{CO}_{2}$ emissions. The increase in resource security was mainly due to the reduction of greenhouse gas emissions and the reduction of the carbon footprint, which was primarily due to the high attention of governments to environmental issues in general and gas emissions standards-the adoption of new standards. Another factor in the growth of the resource security index is the growing development of alternative energy. At the same time, the active growth of resource security during the year (2015-2016) was observed, after which the rapid growth slowed down and turned into a long gradual growth. Since 2017, the growth of the economic security index has strengthened the growth of another of its components, industrial and service security, which is explained, again, by the growing role of China's economy in the world market. 


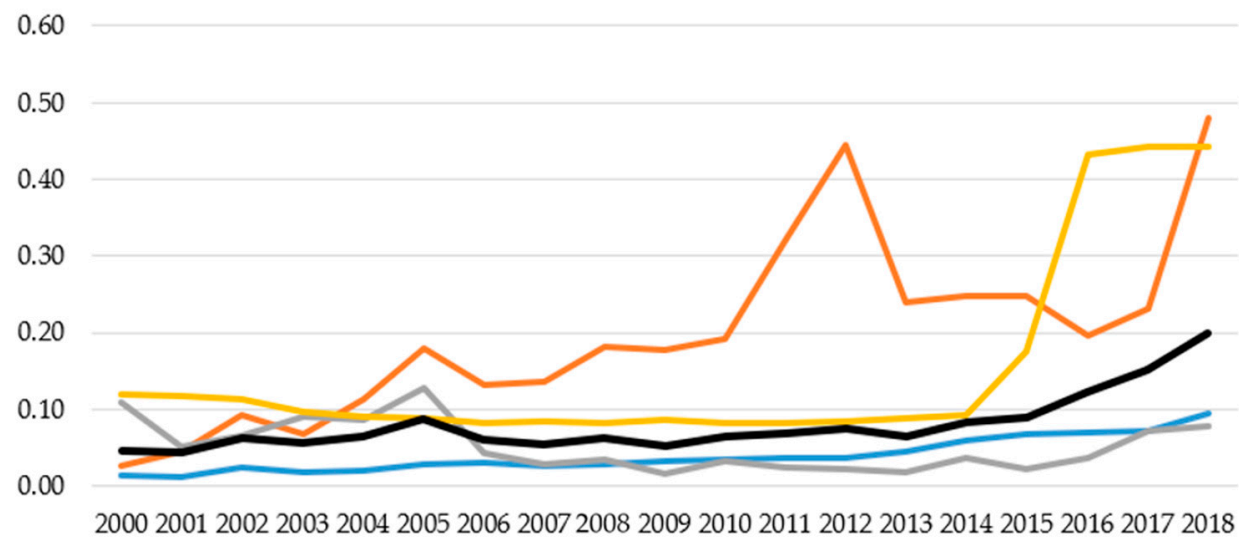

Figure 18. Dynamics of the structural components of the index of economic security in China: blue line-social security index, orange-industrial and service security index, grey-financial and macroeconomic security index, yellow-resource index, and black-economic security index.

The same regression approach revealed the following most impactful energy factors on the economic security index of the countries ("+' means the significant impact) (Table 4).

Table 4. Summed up regression results for all analyzed countries.

\begin{tabular}{|c|c|c|c|}
\hline Indicator & Germany & USA & China \\
\hline Adjusted savings: damage to carbon dioxide (\% of GNI) & + & & \\
\hline Adjusted savings: depletion of minerals (\% of GNI) & + & & \\
\hline Energy consumption from fossil fuels (\% of total volume) & + & & \\
\hline Production of electricity from renewable sources, except hydroelectric power plants (\% of total) & + & & \\
\hline Fuel imports (\% of goods imports) & & + & \\
\hline Adjusted net savings, including loss from greenhouse gas emissions (\% of GNI) & & + & + \\
\hline CO2 emissions (kg per capita in 2011 in GDP) & & + & + \\
\hline Adjusted savings: energy depletion (\% of GNI) & & + & \\
\hline Electricity consumption (kWh per capita) & & + & \\
\hline Renewable electricity production (\% of total electricity output) & & + & \\
\hline Electricity transmission and distribution losses (\% of output) & & & + \\
\hline Generation of energy from renewable sources and waste (\% of total energy) & & & + \\
\hline
\end{tabular}

Energy security, as a functional component of economic security in the context of globalization challenges and the nature of threats, provides opportunities for stable production and use of energy to promote economic growth and improve the quality of life. Therefore, the issue of energy security should be at the strategic level and under close state control [56].

\section{Discussion and Conclusions}

Limitations of the model. The study has several limitations.

First, the analysis of energy security in the world was limited only by the indicators that characterize the supply, consumption, and use of electricity. Of course, electricity plays an important role in society and its energy security, but it is not necessarily an essential one. The process of generating electricity is associated with the use and disposal of energy resources (for instance, oil, gas, coal, and uranium). However, conducting such a study requires significant resources, which makes it impossible to apply it in only one scientific article. Such research should be carried out in the future on different groups of energy indicators.

Second, there may be doubts about the stability of the econometric models that have been built over 28 years. During this time, breakthroughs have been made in the technology of energy production and consumption. In particular, it is worth noting that the emergence of shale technology for gas and oil production, the emergence of installations for obtaining 
wind and solar energy with high efficiency, obtained methods of producing hydrogen with commercial attractiveness. Thus, it may be necessary to determine the stability of the influence of the factors of econometric models that were used in the study.

Third, the volume of work did not allow a study of the issue of geopolitical influence in certain areas on energy and national security. In particular, it may be necessary to consider separate rules for constructing and calculating energy and national security for countries that consume more fossil resources, as well as those that have largely switched to alternative sources.

Fourth, one should note the lack of representative indices of national security that would be available for a long period and the broad list of countries.

Fifth, there is a shortage in the indices of energy security and economic security. Despite the illusion of a variety of them, as one can argue, there is mostly no single one that would have the consideration of the entire list of countries, a stable methodology for the whole period of observations, a long-term trend line, and the open access availability of it. This makes significant forecasting and simulation modeling quite impossible.

In today's world, national, economic, and energy security are interdependent. Despite the broad geopolitical conception [57] that energy security is one of the pillars for national security and can be the cause of the deep tension between states, the national security strategies and the representative national security indices do not prioritize it, in reality. Thus, there is clear research and practical gap to propose the national security index that could be appropriate for the nation, but also for the global assessment that would contain energy security as the principal component.

To date, the increase in the energy generation is uneven. The structure of energy consumption in the countries of the world is also uneven.

However, there is also comforting news. The world is currently undergoing another stage of development, which is associated with the active introduction of technologies for energy production from renewable sources. That is, there is a change in the schedule of the geopolitical forces in the world, as the resources of previous stages are gradually losing their value. It can be concluded that those states that continue to focus on the raw material model of the economy are doomed to a slow death or rapid collapse. It already depends on their characteristics, geopolitical decisions, and margin of safety.

Despite the serious steps to save and conserve energy, there is an increase in its consumption in most countries.

It is likely that there will soon be attempts to reform energy superpowers that, through the control of energy sources, will try to raise prices in this market and carry out further monopolization of it. It can be concluded that such a situation is unlikely to reduce global pollution, and therefore climate change will lead to changes in employment and migration.

In general, the study aimed to monitor how energy security is taken into account in national security. The reason for believing in such a dichotomy is the numerous geopolitical expert opinions and scientific ones, in general, and not only the assumption that most modern inter-country conflicts revolve around energy resources. However, as the literature analysis and review of the world's existing national security indices have shown, the link between energy security and national security is in fact hardly considered. If there is one national security index that mentions energy in its components, it is only from the standpoint of electricity consumption. In general, and in the scientific discourse, most energy security issues, when they are brought to the level of national security issues, are reduced to electricity consumption. Similarly, the scientific discourse is not full of studies of this dichotomy. Based on the lack of any adequate statistical basis for tracking the task, the question was paraphrased as: to find whether the dynamics of energy security is important for the dynamics of economic security as a fundamental component of national security.

The present study contributes to the theory and practice of guaranteeing both energy and national security. From the point of view of the theory, it is offered to define the indices of energy and national security, which will allow for the ranking of countries in accordance to both indicators. From a practical point of view, the analysis showed that there is no 
clear link between the energy and national security indicators in general, which means that energy cannot be considered as the basis for national security, but is only one of the factors for ensuring it. From a social point of view, it is important to realize that the role of energy in the modern world is somewhat exaggerated, which means that any society has the opportunity to build a state with a high level of national security, regardless of the available energy resources.

Author Contributions: Conceptualization, A.S., S.N. and G.K.; methodology, G.K. and A.S.; software, G.K. and A.S.; validation, S.N., D.M., A.S. and G.K.; formal analysis, S.N.; investigation, G.K. and A.S.; resources, G.K., D.M. and S.N.; data curation, A.S. and G.K.; writing—original draft preparation, A.S. and G.K.; writing-review and editing, G.K., D.M. and S.N.; visualization, A.S.; supervision, S.N. and D.M.; project administration, G.K., D.M. and S.N.; funding acquisition, S.N. and D.M. All authors have read and agreed to the published version of the manuscript.

Funding: This research received no external funding.

Institutional Review Board Statement: Not applicable.

Informed Consent Statement: Not applicable.

Data Availability Statement: Free open sources of data are used.

Conflicts of Interest: The authors declare no conflict of interest. 


\section{Appendix A.}

Table A1. The correspondence of the geo-economic and energy situations in the world.

Region

North America

entral and South America
The United States continues to play its role as a superpower. Due to rising energy prices, the country is using a variety of new ideas. Cars with hybrid engines or alternative engines are used. Mexico manages to curb the rise of violence against criminal groups. Canada has hardly changed. It has improved its economy through its energy assets [19].

\section{Energy Security Paradigm in the Region}

In general, the state of energy security in the United States has radically changed over the past decade. In many ways, the country has a strong position to create a reliable, affordable, and environmentally sustainable energy system. In particular, the United States is constantly improving and modernizing energy production: the oil and gas industry through horizontal drilling and hydraulic technology. Harmful emissions from coal mining have declined over the past decade as the United States developed natural gas-fired generators (which are more competitive in the market) during the shale gas boom. Meanwhile, renewable energy sources are also rapidly growing, thanks to lower costs and political support. One part of U.S. energy security is the development of terminals in other countries for LPG exports.

Mexico's population is expected to grow to nearly 150 million by 2050 from 127 million today. Along with increased productivity, this will stimulate economic growth. As a result, energy demand will increase significantly. The energy balance of this country is dominated by oil and gas, with oil accounting for almost half of the total. Mexico has a fast-growing electricity sector and demand has been growing at an average of $1.6 \%$ per year since 2000 Natural gas is a major source of electricity, much of which is imported from the United States and benefits from low gas prices in North America.

Continued anti-Americanism, led by Venezuelan leader Hugo Chavez, has led the state to break away from U.S. influence. Brazil remains the main geopolitical player in the region, which is going through difficult times of restructuring its economy. Venezuela has significant problems, where the economic model does not promote friendly contacts with either its neighbors or the United States. In other countries, a significant demographic growth is observed, which is not supported by economic growth, which complicates social problems within states. Countries are very vulnerable to Brazil's energy policy responds well to the world's most pressing energy challenges. Access to electricity across the country is almost unlimited, and renewable energy sources meet almost $45 \%$ of primary energy demand, making Brazil's energy sector one of the lowest in the world [20]

Fossil fuels are unevenly distributed in Latin America. Oil and gas reserves are concentrated in Venezuela, while most coal reserves are in Colombia and Brazil. In 2020, hydropower dominated Central and South American electricity generation, which accounted for approximately 67 percent of America's total gross domestic production [21] 
Table A1. Cont.

Region Geo-Economic Situation

The EU is trying to gradually expand at the expense of the Balkan countries, but due to the presence of internal

contradictions cannot do it quickly. Significant inhibitions of economic activity in recent years and the inefficiency of part of the economy of education are forcing economic reforms to be carried out, which are not to the liking of member states, which only complicates the situation. Population aging, an influx of migrants, and high unemployment, which do not contribute to solving social problems. In terms of improving living

standards, the EU is actively implementing new environmental standards that affect producers' ability to use scarce resources. At the same time, the EU is interested in diversifying the

supply of resources, which does not allow it to take a tougher stance in negotiations with Russia on future enlargement [23].
Germany created a strategy for energy policy until 2050, which provides for an accelerated withdrawal from nuclear energy by 2022 . France has a very low carbon balance due to well-established policies and the modernization in this sector. France plans to reduce the share of nuclear power plants from $70 \%$ to $50 \%$ in its electricity structure by 2035 , and close its last coal-fired power plants by 2022. Many nuclear reactors are out of service, requiring the modernization of those that can operate in the long run. According to the draft energy policy of Poland until 2040, the share of coal and lignite in electricity production will be reduced to slightly less, by $60 \%$, by 2030 . The draft policy also prioritizes long-term energy security, reducing greenhouse gas emissions and air pollution, improving energy efficiency, and decarbonizing the transport system. In the Czech

Republic, the main goals are to reduce energy consumption, increase the energy intensity of the economy, and expand nuclear energy by about 2500 MW by 2035. Fossil fuels are still a key element of the energy sector in the Czech Republic. Air pollution is a particular problem due to the widespread use of coal and the relatively old car fleet, which is dominated by diesel cars. However, per capita, $\mathrm{CO}_{2}$ emissions and the carbon intensity of the economy are among the highest in Europe. Italy's energy policy is focused on renewable energy sources. The country had impressive success in the renewable energy sector and succeeded in integrating large volumes of renewable generation. In addition, institutional arrangements in the energy sector remain complex and need to be reformed and strengthened. Greece has set targets to reduce greenhouse gas emissions by more than $56 \%$ by 2030 , compared to 2005, and to have a climate-neutral economy by 2050 .

In general, some countries can generate at least $80 \%$ of all electricity from recycling, wind and solar power plants, and biofuels, when introducing alternative energy sources. EU countries plan to ban internal combustion engines in the next 15 years, which will significantly change the structure of energy consumption.

The government is implementing reforms to standardize and simplify the licensing procedures for renewable energy projects and is exploring options for using offshore wind energy. The Greek islands also have renewable energy projects to decarbonize electricity $[23,24]$ 
Table A1. Cont.

Region

The Middle East and Middle Asia
Iraq continues to thrive despite attacks by insurgents and terrorists. US troops are leaving the country. Advisers and some combat units remained to assist the Iranians in ensuring security. Iraq supports new European gas and oil pipelines to Turkey. There are tensions with Iran-radical Islamists and democratic groups plunge the country's major cities into civil war. Not wanting to risk losing refineries, the United States is developing a strategy to find new fields.

Recent developments in Libya, along with ongoing territoria disputes between several Eastern Mediterranean countries, especially the disputes between Turkey, Greece, and Cyprus over their respective SEZs, have hampered the exploration and development of the region, especially in the Levant Sea basin. If geopolitics is an argument for the future world order, then the Eastern Mediterranean, like no other, is becoming a cauldron of conflicting views and interests. The geopolitical interests of the Eastern Mediterranean countries will inevitably influence geoeconomic decisions regarding the flow and exchange of traded gas [25].

The Middle East is experiencing a series of geopolitical crises and wars involving the shifting role of oil in the global economy and the attempts to secure or redistribute those incomes. Most of the conflicts are related to oil-bearing countries, namely Libya, Syria, Turkey, Iraq, Iran, Azerbaijan, Saudi Arabia, and Yemen.

\section{Energy Security Paradigm in the Region}

In the struggle for energy routes, naval conflicts in the Eastern Mediterranean are intensifying. The risk of confrontation between regional states is growing. The development of the maritime border dispute between Turkey, Greece, and France is accelerating and deepening. The belligerent statements and threats of high-ranking government officials from the three countries, accompanied by numerous military conflicts, still bypass diplomatic relations aimed at overcoming a future clash between two- or possibly three-NATO members. At the heart of the recent crisis between Greece and Turkey is a dangerous ideological model, not just a dispute over energy resources. The oil blockade in Libya has been going on for 9 months, and oil production in the war-torn country fluctuates only at 100,000 barrels per day instead of the pre-crisis 1.2 million barrels per day.

The COVID-19 pandemic is just the tip of the iceberg of the socio-political and economic problems of the Eastern Mediterranean. What makes the Eastern Mediterranean so incendiary today is the combination of several complex and volatile issues, including historical ambitions, conflicting claims to sovereignty, competition for control of newly discovered natural gas reserves, pipeline policy, civil wars and political chaos in coastal states, reduction in U.S. states, the expansion of the Russian naval base in Syria, the expansion of Turkey in Libya, the differences between NATO allies, and the waves of migration and refugees.

The collective interest in mobilizing the Eastern Mediterranean's gas reserves has expanded cooperation between Greece, Cyprus, Israel, and Egypt, as well as key energy companies from the United States, Israel, Italy, and France. This group has grown to include Italy, Jordan, and Palestine, culminating in the creation of the Eastern Mediterranean Gas Forum (EMGF).

Middle Eastern countries have different understandings of energy security. If the pennies of the state will be energy-neutral economies, where the role of alternative energy sources is constantly growing, then others are trying to maintain their role as major producers of oil and gas. To do this, there is a struggle for new markets, including liquefied natural gas. 
Table A2. National security vs/along with energy security: correlations and causality studies.

\begin{tabular}{|c|c|c|c|c|}
\hline Scope of the Research & $\begin{array}{l}\text { State and Period } \\
\text { under Analysis }\end{array}$ & The Goal of the Research & Mathematical Approach Used & Results Obtained \\
\hline $\begin{array}{l}\text { Evaluation of energy security as a } \\
\text { component of the national security } \\
\text { of the country [2] }\end{array}$ & $\begin{array}{l}\text { 2011-2017, Russia, China, } \\
\text { U.S.A., Czech Rep., Poland, } \\
\text { Sweden, and Germany }\end{array}$ & $\begin{array}{l}\text { To calculate and select the indicators } \\
\text { of energy independence. }\end{array}$ & $\begin{array}{l}\text { The multidimensional mean, the } \\
\text { selection of statistical indicators, the } \\
\text { choice of the base of their normalization, } \\
\text { the use of the analytic hierarchy process } \\
\text { for the evaluation of weighting } \\
\text { coefficients, the method of aggregation } \\
\text { of indicators in the integrated evaluation } \\
\text { of energy independence, and analysis of } \\
\text { the time series. }\end{array}$ & $\begin{array}{l}\text { The country's energy independence requires quantitative } \\
\text { evaluation to ensure regulatory actions in this area of } \\
\text { government activity. To do this, it is necessary to } \\
\text { highlight the most significant both absolute and relative } \\
\text { indicators, which evaluate the country's } \\
\text { energy independence. }\end{array}$ \\
\hline $\begin{array}{l}\text { Evaluation of sustainable energy } \\
\text { security and an empirical analysis of } \\
\text { China [27] }\end{array}$ & China, 2004-2015 & $\begin{array}{l}\text { Study of the impact of geopolitics on } \\
\text { China's energy security, achieving } \\
\text { sustainable development of the } \\
\text { national energy system as a decisive } \\
\text { factor in the country's development. } \\
\text { Creation of a theoretical system of } \\
\text { energy evaluation }\end{array}$ & $\begin{array}{l}\text { China's Sustainable Energy Security } \\
\text { (CSES) index calculation, its empirical } \\
\text { study for 2004-2015. The initial values of } \\
\text { each indicator were calculated by the } \\
\text { min _max method, and a matrix of } \\
\text { solutions was constructed. }\end{array}$ & $\begin{array}{l}\text { The measures that need to be taken by government } \\
\text { agencies to support the goals of energy security and } \\
\text { energy sustainability are recommended. The priority of } \\
\text { the development of clean energy in the strengthening of } \\
\text { coefficient of energy self-sufficiency is specified. }\end{array}$ \\
\hline $\begin{array}{l}\text { Estimating the interrelation between } \\
\text { energy security and macroeconomic } \\
\text { factors in European countries [1] }\end{array}$ & 1997-2016, $28 \mathrm{EU}$ & $\begin{array}{l}\text { Analysis of energy security in some } \\
\text { European countries and the } \\
\text { assessment of energy security. } \\
\text { Defining how the level of energy } \\
\text { security is related to the main } \\
\text { macroeconomic parameters } \\
\text { of countries. }\end{array}$ & $\begin{array}{l}\text { Calculation of the Shannon-Wiener } \\
\text { index, its comparison with the share of } \\
\text { energy from renewable sources, and } \\
\text { NESI representation. Development of a } \\
\text { new energy security index NESI, which } \\
\text { thoroughly describes the real threats and } \\
\text { opportunities of European countries in } \\
\text { terms of energy security. Based on } \\
\text { energy consumption, production, } \\
\text { distribution, and efficiency. }\end{array}$ & $\begin{array}{l}\text { Indication of the shortcomings of the existing energy } \\
\text { security indices. Analysis of the ratio of the NESI index } \\
\text { with the main macroeconomic indicators in different } \\
\text { European countries } \\
\text { GDP growth is positively correlated with NESI and } \\
\text { negatively with CPI. Therefore, on the one hand, } \\
\text { economic instruments can improve energy security in } \\
\text { Europe, and, on the other hand, guaranteeing energy } \\
\text { security leads to lower prices and increased } \\
\text { national production. } \\
\text { The study helps to identify the most valuable EU } \\
\text { countries for energy security, which will suffer the most } \\
\text { in the case of, for example, the destruction of a single gas } \\
\text { system. Using NESI can help understand how countries } \\
\text { respond to international change if they can sustain the } \\
\text { required level of technological change in energy } \\
\text { production and distribution. }\end{array}$ \\
\hline
\end{tabular}


Table A2. Cont.

\begin{tabular}{|c|c|c|c|c|}
\hline Scope of the Research & $\begin{array}{c}\text { State and Period } \\
\text { under Analysis }\end{array}$ & The Goal of the Research & Mathematical Approach Used & Results Obtained \\
\hline $\begin{array}{l}\text { National energy security assessment } \\
\text { from a geopolitical perspective [28] }\end{array}$ & Italy & $\begin{array}{l}\text { An overarching methodology is } \\
\text { outlined to evaluate energy security, } \\
\text { in which its external and internal } \\
\text { dimensions are considered and } \\
\text { integrated: the security of the energy } \\
\text { supply from abroad (external) and } \\
\text { the security of national energy } \\
\text { infrastructures (internal). }\end{array}$ & $\begin{array}{l}\text { Two indexes are defined using a } \\
\text { probabilistic approach. }\end{array}$ & $\begin{array}{l}\text { The evaluation of energy security needs to consider } \\
\text { different dimensions and is of the utmost importance as a } \\
\text { benchmark to conceive and implement different policies. }\end{array}$ \\
\hline
\end{tabular}




\section{Appendix B. Regression Results}

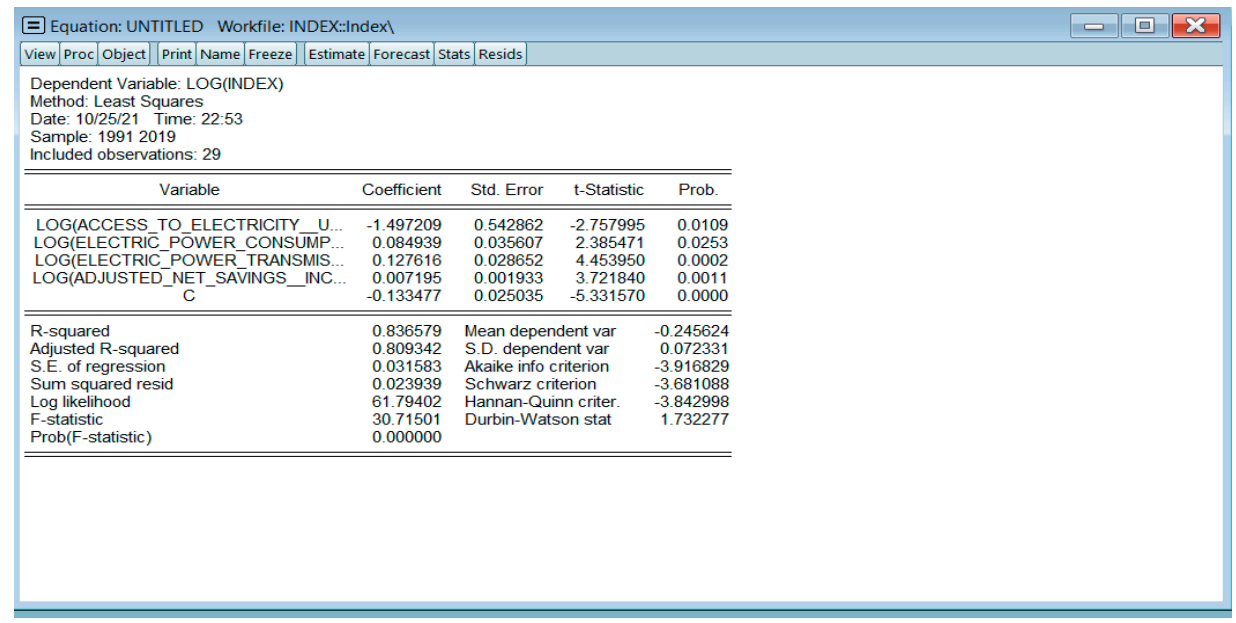

Figure A1. Eviews regression result (Ukraine case).

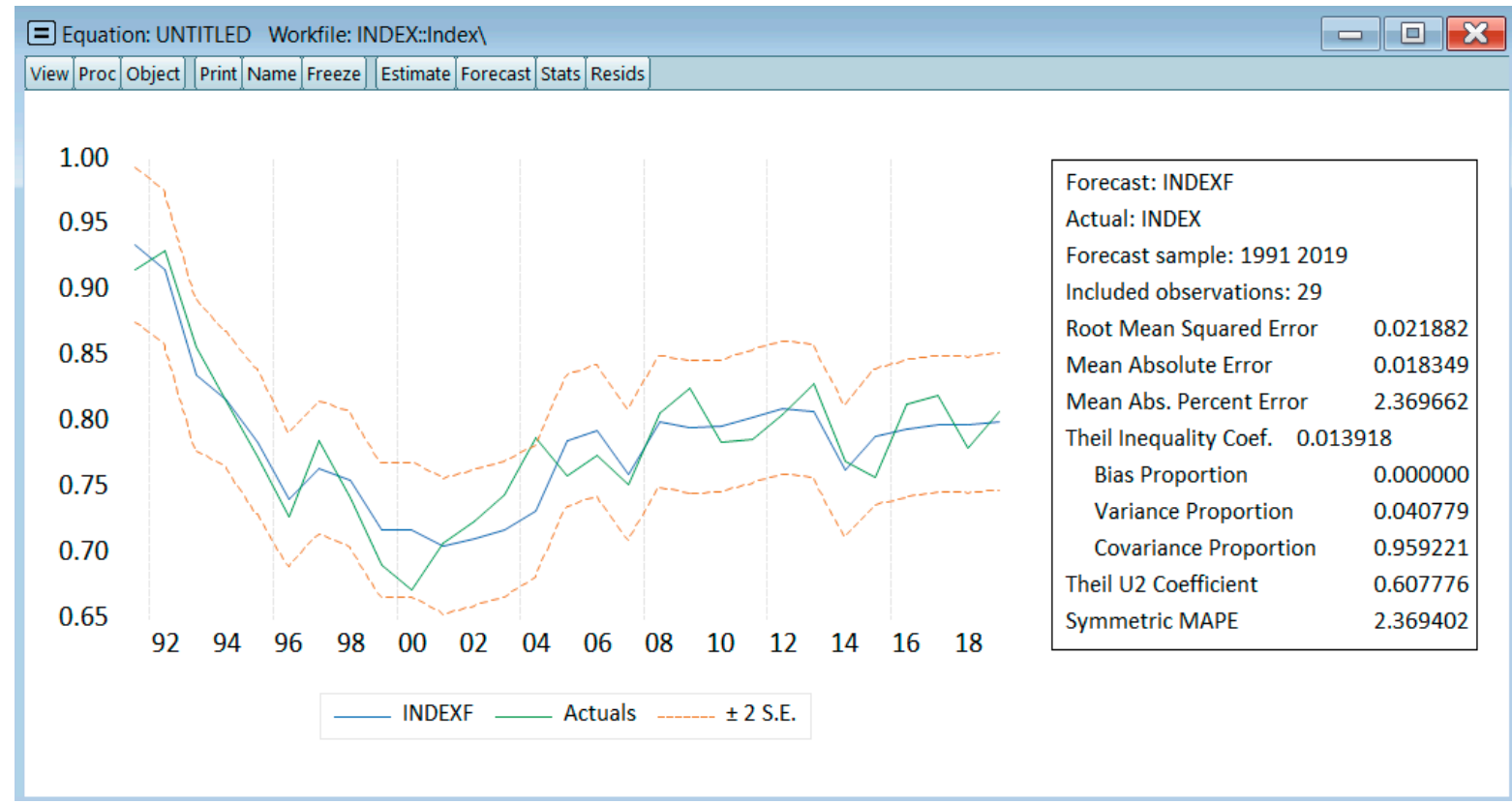

Figure A2. Forecasting according to the regression model for Ukraine.

\section{References}

1. Stavytskyy, A.V.; Kharlamova, G.; Giedraitis, V.; Šumskis, V. Estimating the interrelation between energy security and macroeconomic factors in European countries. J. Int. Stud. 2018, 11, 217-238. [CrossRef]

2. Dźwigoł, H.; Dźwigoł-Barosz, M.; Zhyvko, Z.; Miśkiewicz, R.; Pushak, H. Evaluation of the energy security as a component of national security of the country. J. Secur. Sustain. Issues 2019, 8, 307-317. [CrossRef]

3. Song, Y.; Ming, Z.; Ruifeng, S. Using a new aggregated indicator to evaluate China's energy security. Energy Policy 2019, 132, 167-174. [CrossRef]

4. Nate, S.; Bilan, Y.; Cherevatskyi, D.; Kharlamova, G.; Lyakh, O.; Wosiak, A. The impact of energy consumption on the three pillars of sustainable development. Energies 2021, 14, 1372. [CrossRef]

5. Chernyak, O.; Kharlamova, G.; Stavytskyy, A. Trends of international energy security risk index in European countries. TalTech J. Eur. Stud. 2018, 8, 5-32. [CrossRef]

6. Kharazishvili, Y.; Kwilinski, A.; Sukhodolia, O.; Dzwigol, H.; Bobro, D.; Kotowicz, J. The systemic approach for estimating and strategizing energy security: The case of Ukraine. Energies 2021, 14, 2126. [CrossRef]

7. Stavytskyy, A. Influence of modern geopolitical challenges on state's economic security. Bull. Taras Shevchenko Natl. Univ. Kyiv. Econ. 2018, 4, 45-55. [CrossRef] 
8. Blazev, A.S. Energy Security for the 21st Century; River Publishers: Aalborg, Denmark, 2021.

9. Tvaronavičiene, M. Innovation in Energy Security and Long-Term Energy Efficiency. 2020. Available online: https://www.mdpi. com/books/pdfview/book/2752 (accessed on 28 November 2021).

10. Wang, B.; Wang, Q.; Wei, Y.M.; Li, Z.P. Role of renewable energy in China's energy security and climate change mitigation: An index decomposition analysis. Renew. Sustain. Energy Rev. 2018, 90, 187-194. [CrossRef]

11. Zhang, L.; Yu, J.; Sovacool, B.K.; Ren, J. Measuring energy security performance within China: Toward an inter-provincial prospective. Energy 2017, 125, 825-836. [CrossRef]

12. National Bureau of Statistics of China. Available online: http:/ /www.stats.gov.cn/english/ (accessed on 10 October 2021).

13. Kemp, J.C.; China's Five-Year Plan Focuses on Energy Security. Reuters. Available online: https://www.reuters.com/article/uscolumn-china-energy-kemp-idUSKBN2BB1Y1 (accessed on 15 October 2021).

14. Our World in Data. States. Available online: https: / / ourworldindata.org/energy/country/ (accessed on 10 October 2021).

15. Li, M.; Li, L.; Strielkowski, W. The impact of urbanization and industrialization on energy security: A case study of China. Energies 2019, 12, 2194. [CrossRef]

16. Kenderdine, M.; Hochstein, A. Valuation of Energy Security for the United States; Report to Congress; U.S. Department of Energy: Washington, DC, USA, 2017.

17. Stocking, A.; Kyle, J.; Moore, D. Energy Security in the United States; Congressional Budget Office Report; CBO: Washington, DC, USA, 2012

18. The Global Economy. Available online: https://www.theglobaleconomy.com/rankings/external_interventions_index/(accessed on 10 October 2021).

19. Stavytskyy, A. Geopolitical climate of Black Sea region. In Emerging Importance of Wider Black Sea Area Security; Lucian Blaga University of Sibiu: Sibiu, Romania, 2018; pp. 107-117.

20. STATISTA. Electricity Generation in South and Central America in 2020, by Fuel Type. Available online: https: / www.statista com/statistics/983336/central-south-america-electricity-generation-source/ (accessed on 20 October 2021).

21. Balza, L.H.; Espinasa, R.; Serebrisky, T. Lights on? Energy Needs in Latin America and the Caribbean to 2040; Inter-American Development Bank: Washington, DC, USA, 2016; Available online: https://publications.iadb.org/publications/english/document/LatinAmerica-Energy-Future.pdf (accessed on 20 October 2021).

22. Energy Wars Map. Available online: https://www.deviantart.com/paintfan08/art/Energy-Wars-Map-118715749 (accessed on 20 October 2021).

23. International Energy Agency. Available online: https://www.iea.org/countries/ (accessed on 25 October 2021).

24. Energy Wars and Naval Diplomacy in the Mediterranean. 2020. Available online: https://www.semedenergydefense.com/ report-7-energy-wars-and-naval-diplomacy-in-the-mediterranean/ (accessed on 25 October 2021).

25. Energy Security in the Epoch of Hybrid Wars. 2021. Available online: https://www.nato.int/docu/review/uk/articles/2021/01/ 13/energetichna-bezpeka-v-dobu-gbridnih-von/index.html (accessed on 25 October 2021).

26. Norouzi, N.; Fani, M. The impacts of the novel corona virus on the oil and electricity demand in Iran and China. J. Energy Manag. Technol. 2020, 4, 36-48.

27. Walker, M. Russia v. Europe: The energy wars. World Policy J. 2007, 24, 1-8. [CrossRef]

28. Demetrious, K. 'Energy wars': Global PR and public debate in the 21st century. Public Relat. Inq. 2019, 8, 7-22. [CrossRef]

29. Wolfe, W.M.; Tessman, B.F. China's global equity oil investments: Economic and geopolitical influences. J. Strateg. Stud. 2012, 35, 175-196. [CrossRef]

30. Le Billon, P. The geopolitical economy of 'resource wars'. Geopolitics 2004, 9, 1-28. [CrossRef]

31. Moran, D.; Russell, J.A. Energy Security and Global Politics: The Militarization of Resource Management; Routledge: Abington-onThames, UK, 2008; Volume 6.

32. Samaras, C.; Nuttall, W.J.; Bazilian, M. Energy and the military: Convergence of security, economic, and environmental decisionmaking. Energy Strategy Rev. 2019, 26, 100409. [CrossRef]

33. Alshwawra, A.; Almuhtady, A. Impact of regional conflicts on energy security in Jordan. Int. J. Energy Econ. Policy 2020, 10, 45. [CrossRef]

34. Bichler, S.; Nitzan, J. Energy conflicts and differential profits: An update. Res. Note 2014, 1-5. Available online: http:/ / pinguet. free.fr/bichler1014.pdf (accessed on 30 November 2021).

35. Stergiou, A.; Karagianni, M. Does Energy Cause Ethnic War? East Mediterranean and Caspian Sea Natural Gas and Regional Conflicts; Cambridge Scholars Publishing: Newcastle upon Thyme, UK, 2019.

36. Perović, J. Cold War Energy: A Transnational History of Soviet Oil and Gas; Springer: Berlin/Heidelberg, Germany, 2017.

37. Twenty-First-Century Energy Wars: How Oil and Gas Are Fuelling Global Conflicts. 2014. Available online: https://energypost. eu/twenty-first-century-energy-wars-oil-gas-fuelling-global-conflicts/ (accessed on 25 October 2021).

38. Fang, D.; Shanshan, S.; Qian, Y. Evaluation of sustainable energy security and an empirical analysis of China. Sustainability 2018, 10, 1685. [CrossRef]

39. Bompard, E.; Carpignano, A.; Erriquez, M.; Grosso, D.; Pession, M.; Profumo, F. National energy security assessment in a geopolitical perspective. Energy 2017, 130, 144-154. Available online: https://www.sciencedirect.com/science/article/abs/pii/ S0360544217306746 (accessed on 25 October 2021). [CrossRef] 
40. Mottaghi, E.; Davoudi, M. An introduction to energy security, national security and citizenship (case study of Iran). J. Res. Energy Law Stud. 2021, 7, 211-227.

41. Miśkiewicz, R. The Impact of Innovation and Information Technology on Greenhouse Gas Emissions: A Case of the Visegrád Countries. J. Risk Financ. Manag. 2021, 14, 59. [CrossRef]

42. Stavytskyy, A.; Kharlamova, G.; Komendant, O.; Andrzejczak, J.; Nakonieczny, J. Methodology for calculating the energy security index of the state: Taking into account modern megatrends. Energies 2021, 14, 3621. [CrossRef]

43. Kharlamova, G.; Stavytskyy, A.; Nate, S. Estimation of renewable energy sources application in the synergy with European Union policy Bull. Taras Shevchenko Natl. Univ. Kyiv. Econ. 2018, 3, 54-65. [CrossRef]

44. Kobko, Y. Monitoring of Threats to the State National Security: Foreign Experience and Ukrainian Realities of Public-Legal Provision. 2018. Available online: http://nvppp.in.ua/vip/2018/4/tom_2/38.pdf (accessed on 28 October 2021).

45. Samosevich, V.A. Ensuring the National Security of Germany and Belarus: A Comparative Analysis. 2007. Available online: https://studme.org/172870/politologiya/obespechenie_natsionalnoy_bezopasnosti_germanii (accessed on 1 October 2020).

46. Financial Express. National Security Index. Available online: https://www.financialexpress.com/archive/national-securityindex/73254/ (accessed on 1 October 2020).

47. Security Threat Index. The Global Economy. Available online: https://www.theglobaleconomy.com/rankings/security_threats_ index/ (accessed on 28 October 2021).

48. Global Energy Institute. Available online: https:/ / www.globalenergyinstitute.org/energy-security-risk-index (accessed on 28 October 2021).

49. National Institute for Strategic Studies. Ukraine. Available online: https://niss.gov.ua/sites/default/files/2013-01/ruzuku_dod. pdf (accessed on 28 October 2021).

50. Energy Trillema Index. World Energy Council. Available online: https://www.worldenergy.org/assets/downloads/ WETrilemma_2019_Full_Report_v4_pages.pdf (accessed on 28 November 2021).

51. World Energy Council. Available online: https:/ / www.worldenergy.org/ (accessed on 28 November 2021).

52. Cech, M. Panel Regression Analysis of Electricity Prices and Renewable Energy in the European Union. 2016. Available online: https:/ / mpra.ub.uni-muenchen.de/74640/1/MPRA_paper_74601.pdf (accessed on 28 November 2021).

53. Boneva, S. Analysis of the Energy Dependence of the European Union. 2021. Available online: https://revistia.com/files/ articles/ejes_v4_i1_18/Boneva.pdf (accessed on 28 November 2021).

54. Asteriou, D.; Hall, S.G. Applied Econometrics; Macmillan International Higher Education: London, UK, 2015.

55. Stavytskyy, A. Economic Security of Ukraine: Strategy and Support Mechanisms: Monograph; Agrar Media Group: Kyiv, Ukraine, 2018.

56. Kharlamova, G.; Stavytskyy, A.; Chernyak, O. Analysis of energy security provision in the European Countries. In Innovative Business Development—A Global Perspective; IECS 2018; Orăștean, R., Ogrean, C., Mărginean, S., Eds.; Springer: Cham, Switzerland, 2018; pp. 111-131. [CrossRef]

57. Global Energy Institute. The International Energy Security Risk Index. Available online: https://www.globalenergyinstitute.org/ international-energy-security-risk-index (accessed on 28 October 2021). 